\title{
Survey on \\ opportunities and \\ barriers in lighting controls
}

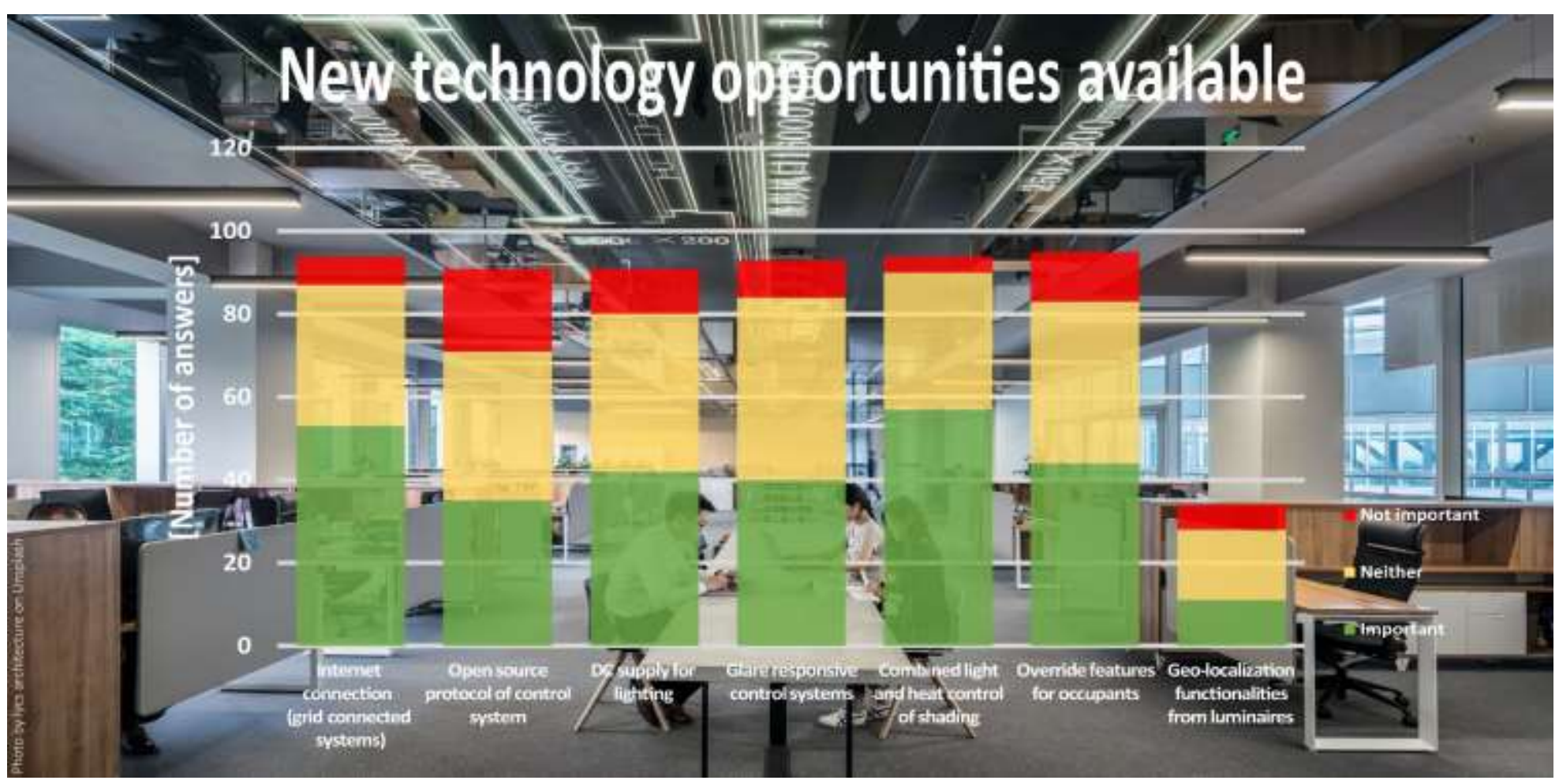

IEA SHC Task 61 / EBC Annex 77: Integrated Solutions for Daylighting and Electric Lighting 


\section{IEA Solar Heating and Cooling Technology Collaboration Programme (IEA SHC)}

The Solar Heating and Cooling Technology Collaboration Programme was founded in 1977 as one of the first multilateral technology initiatives ("Implementing Agreements") of the International Energy Agency. Its mission is "To enhance collective knowledge and application of solar heating and cooling through international collaboration to reach the goal set in the vision of solar thermal energy meeting $50 \%$ of low temperature heating and cooling demand by $2050 . "$

The members of the IEA SHC collaborate on projects (referred to as Tasks) in the field of research, development, demonstration (RD\&D), and test methods for solar thermal energy and solar buildings.

Research topics and the associated Tasks in parenthesis include:

- Solar Space Heating and Water Heating (Tasks 14, 19, 26, 44, 54)

- Solar Cooling (Tasks 25, 38, 48, 53, 65)

- Solar Heat for Industrial or Agricultural Processes (Tasks 29, 33, 49, 62, 64)

- Solar District Heating (Tasks 7, 45, 55)

- Solar Buildings/Architecture/Urban Planning (Tasks 8, 11, 12, 13, 20, 22, 23, 28, 37, 40, 41, 47, 51, 52, 56, 59, 63)

- Solar Thermal \& PV (Tasks 16, 35, 60)

- Daylighting/Lighting (Tasks 21, 31, 50,61)

- Materials/Components for Solar Heating and Cooling (Tasks 2, 3, 6, 10, 18, 27, 39)

- Standards, Certification, and Test Methods (Tasks 14, 24, 34, 43, 57)

- Resource Assessment (Tasks 1, 4, 5, 9, 17, 36, 46)

- Storage of Solar Heat (Tasks 7, 32, 42, 58)

In addition to our Task work, other activities of the IEA SHC include our:

> International Conference on Solar Heating and Cooling for Buildings and Industry

$>$ SHC Solar Academy

$>$ Solar Heat Worldwide annual statics report

$>$ Collaboration with solar thermal trade associations

\section{Country Members}

$\begin{array}{lll}\text { Australia } & \text { France } & \text { South Africa } \\ \text { Austria } & \text { Germany } & \text { Spain } \\ \text { Belgium } & \text { Italy } & \text { Sweden } \\ \text { Canada } & \text { Netherlands } & \text { Switzerland } \\ \text { China } & \text { Norway } & \text { Turkey } \\ \text { Denmark } & \text { Portugal } & \text { United Kingdom } \\ \text { European Commission } & \text { Slovakia } & \end{array}$

\section{Sponsor Members}

European Copper Institute

ECREEE

International Solar Energy Society

RCREEE

CCREEE

RCREEE

EACREEE

SACREEE

For more information on the IEA SHC work, including many free publications, please visit www.iea-shc.org. 


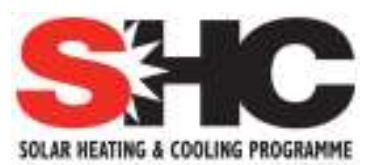

INTERNATIONAL ENERGY AGENCY

\section{Survey on \\ opportunities and barriers in lighting controls}

Editor: Marc Fontoynont

Authors (in alphabetical order):

Bruno Bueno Unzeta, Jan de Boer, Ruben Delvaeye, Bertrand Deroisy, Marc Fontoynont, David Geisler-Moroder, Niko Gentile, Tao Luo, Daniel Neves Pimenta, Per Reinhold, Michelangelo Scorpio, Sergio Sibilio, Natalia Sokól, Sophie Stoffer, Robert Weitlaner

\section{1-02-17}

DOI: 10.18777/ieashc-task61-2021-0002

\section{T61.B.1, A Technical Report of Subtask B}

The contents of this report do not necessarily reflect the viewpoints or policies of the International Energy Agency (IEA) or its member countries, the IEA Solar Heating and Cooling Technology Collaboration Programme (SHC TCP) members or the participating researchers. 
Bruno BUENO UNZETA

Fraunhofer Institute for Solar Energy Systems

ISE

Heidenhofstr. 2,

79110 Freiburg i. Br.

Germany

bruno.bueno@ise.fraunhofer.de

Jan DE BOER

Fraunhofer Institute for Building Physics IBP Nobelstr. 12,

70569 Stuttgart

Germany

jan.deboer@ibp.fraunhofer.de

Ruben DELVAEYE

Belgian Building Research Institute (BBRI)

Avenue Pierre Holoffe, 21,

1342 Limelette

Belgium

ruben.delvaeye@bbri.be

Bertrand DEROISY

Belgian Building Research Institute

Avenue P. Holoffe 21

1342 Limelette

Belgium

bertrand.deroisy@bbri.be

\section{Marc FONTOYNONT}

BUILD - Institut for Byggeri, By og Milje

A.C. Meyers Vænge 15,

2450 København SV

Denmark

mfo@build.aau.dk

David GEISLER-MORODER

Bartenbach $\mathrm{GmbH}$

Rinner Strasse 14

6071 Aldrans

Austria

david.geisler-moroder@bartenbach.com

\section{Niko GENTILE}

Lund University

Sörvegatan 24,

22100 Lund

Sweden

niko.gentile@ebd.Ith.se

\section{Tao LUO}

China Academy of Building Research

No.30 Beisanhuan East Road,

100013 Beijing

China

daylighting@126.com
Daniel NEVES PIMENTA

Fraunhofer Institute for Building Physics IBP

Nobelstr. 12,

70569 Stuttgart

Germany

daniel.neves.pimenta@ibp.fraunhofer.de

Per REINHOLD

Dansk Center for Lys (Danish Lighting Center)

Borupvang 9,

2750 Ballerup

Denmark

pr@centerforlys.dk

Michelangelo SCORPIO

University of Campania

Abbey of San Lorenzo in Septimum,

81031 - Aversa (CE)

Italy

michelangelo.scorpio@unicampania.it

\section{Sergio SIBILIO}

University of Campania

Abbey of San Lorenzo in Septimum,

81031 - Aversa (CE)

Italy

sergio.sibilio@unicampania.it

Natalia SOKÓL

Gdansk University of Technology

Gabriela Narutowicza 11/12,

80-233 Gdańsk

Poland

natalia.sokol1@pg.edu.pl

Sophie STOFFER

BUILD - Institut for Byggeri, By og Miljø

A.C. Meyers Vænge 15,

2450 København SV

Denmark

asls@build.aau.dk

Robert WEITLANER

HELLA Sonnen- und Wetterschutztechnik

$\mathrm{GmbH}$

9913 Abfaltersbach 125

Austria

robert.weitlaner@hella.info 


\section{KEYWORDS}

Integrated daylighting and electric Lighting, opportunities and barriers in lighting controls, lighting controls, survey lighting controls

\section{ACKNOWLEDGEMENTS}

The authors thank their respective funding agencies for supporting their work:

Denmark: ELFORSK (Contract EUDP 64017-05110) 


\section{PREFACE}

Lighting accounts for approximately $15 \%$ of the global electric energy consumption and $5 \%$ of greenhouse gas emissions. Growing economies, higher user demands for quality lighting and rebound effects as a result of low priced and more versatile electric lighting continuously still lead to an absolute increase of lighting energy consumption. More light is used, often less consciously.

Especially the electric lighting market but as well the façade, daylighting und building automation sectors have seen significant technological developments in the past decade. However these sectors still act mainly independent of each other, leaving out big potentials lying in a better technology and market integration. This integration is on the one hand beneficial to providing better user-centred lighting of indoor spaces. On the other hand it can contribute significantly to the reduction of worldwide electricity consumptions and C02-emissions, which is in line with several different governmental energy efficiency and sustainability targets.

IEA SHC Task 61 / EBC Annex 77 "Integrated Solutions for daylighting and electric lighting - From Component to system efficiency" therefore pursues the goal to support and foster the better integration of electric lighting and daylighting systems including lighting controls with a main focus on the non-residential sector. This includes the following activities:

- Review relation between user perspective (needs/acceptance) and energy in the emerging age of "smart and connected lighting" for a relevant repertory of buildings.

- Consolidate findings in use cases and "personas" reflecting the behaviour of typical users.

- Based on a review of specifications concerning lighting quality, non-visual effects as well as ease of design, installation and use, provision of recommendations for energy regulations and building performance certificates.

- Assess and increase robustness of integrated daylight and electric lighting approaches technically, ecologically and economically.

- Demonstrate and verify or reject concepts in lab studies and real use cases based on performance validation protocols.

- Develop integral photometric, user comfort and energy rating models (spectral, hourly) as prenormative work linked to relevant bodies: CIE, CEN, ISO. Initialize standardization.

- Provide decision and design guidelines incorporating virtual reality sessions. Integrate approaches into wide spread lighting design software.

- Combine competencies: Bring companies from electric lighting and façade together in workshops and specific projects. Hereby support allocation of added value of integrated solutions in the market.

To achieve this goal, the work plan of IEA SHC Task 61 / EBC Annex 77 is organized according to the following four main subtasks, which are interconnected by a joint working group:

- Subtask A:

- Subtask B:

- Subtask C:

Guidelines)

- Subtask D:

- Joint Working Group:
User perspective and requirements

Integration and optimization of daylight and electric lighting

Design support for practitioners (Tools, Standards,

Lab and field study performance tracking

Evaluation tool \& VR Decision Guide

Subtask B focuses on the evolution of the technologies and identifies new opportunities offered by control systems for lighting and daylighting systems, with the objective to improve energy performance as well as improving operation by occupants and facility managers. 


\section{EXECUTIVE SUMMARY}

This report summarizes a survey performed in eight countries on the status quo of daylight and electric lighting control systems. Feedback from more than 100 international experts (building / facility managers and planers) was evaluated. The aim of the survey was to identify the perception of the different possibilities of the current lighting control solutions and the expectations about the control systems. The survey aims to provide a mapping of the current lighting control systems available at the market and an overview of which functions are perceived as most important and which areas are found to be improved. Participants of the survey had to rank each question in relation to the perceived importance and the need for improvement. The survey enclosed five general topics; energy, operational aspects, occupant control, occupant comfort and control functionality.

The findings from the summary suggest, that the two main reasons for the implementation of lighting control systems are:

1. The possibility to reduce the electric lighting consumptions and

2. The opportunity to increase the user's well-being and thereby reduce complaints from the users.

From a user perspective, this means that the lighting system must ensure visual acuity and comfort by providing a sufficient level of illuminance and the ability to regulate the light level. Always in relation to the task and the ambient light in the space, and thereby creating a pleasant and comfortable light environment. Research suggests, when giving the users some manual control possibilities, the satisfaction with the lighting conditions in general increases The users should be able to both increase and dim the light levels or completely turn it off. This suggests, if the lighting control system is designed to regulate the illuminance automatically, it should be provided some kind of manual override. This is supported by the findings in the surveys, where all countries in one way or another find it important to provide the users with some possibility of user control. This as well applies to the control of the shading system in relation to avoid glare from high daylight intensities and undesired solar radiation coming into the space. This increases the risk of overheating, resulting in an increased ventilation and/or cooling need leading to a higher energy use. However, in the two Scandinavian countries, it is found less important with the possibility to control the shadings in order to reduce glare from daylight and undesired heat transmission in the space. This may be due to the higher latitude and thereby a lower intensity of the daylight.

In relation to the importance of user control, the findings additionally suggest, that the occupant control must be simple to operate. A control system which is easy for the users to understand intuitive, will most likely increase the chances of an 'optimal' interaction with the system. If the system does not meet the users need or is too complex to use, the possibility that the users will try to override the control systems increases, and this will most likely result in increased energy consumption. 


\section{Contents}

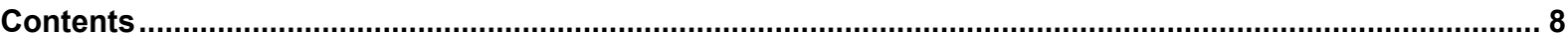

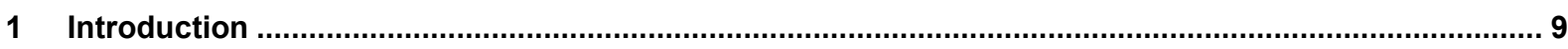

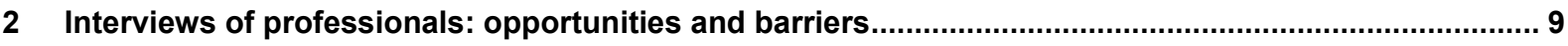

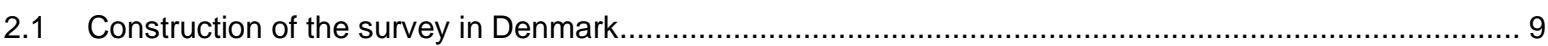

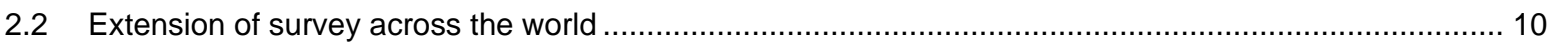

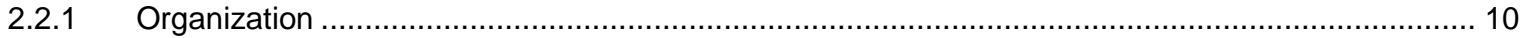

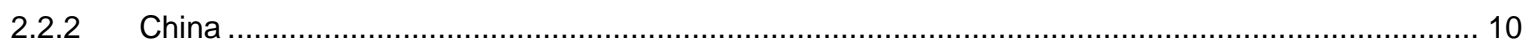

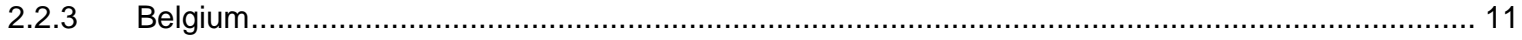

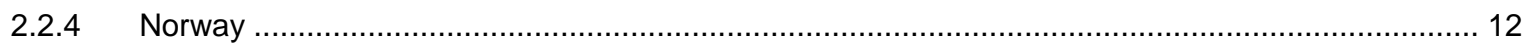

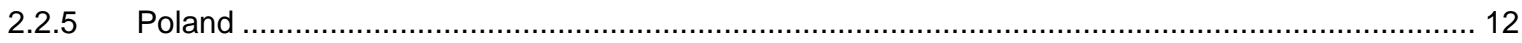

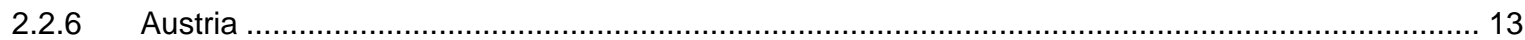

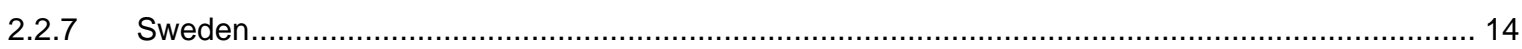

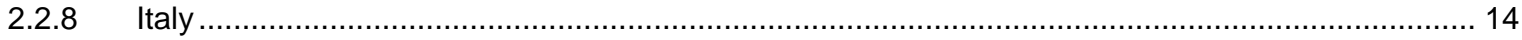

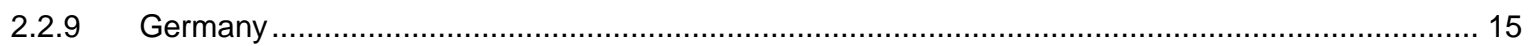

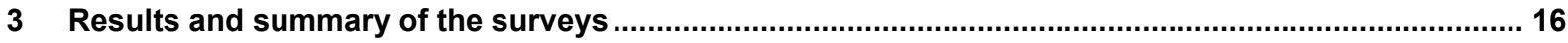

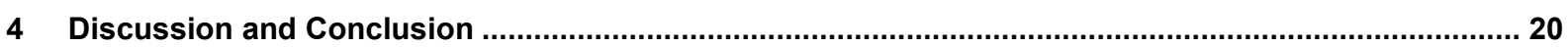

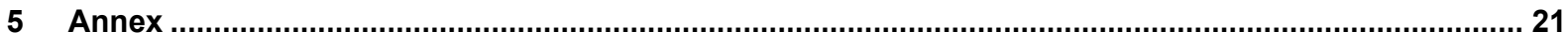




\section{Introduction}

The technology of lighting and shading controls has been affected significantly by the evolution towards the use of building management systems (BMS). Beyond the traditional aspects such as HVAC, lighting, security and fire safety, these systems can now integrate domains such as data communication and geo-localization. They are also able to collect and interpret data from a wide variety of sensors. Communication opens up to wireless protocols, offering more flexibility: systems can be modified in line with the evolution of the buildings and their spaces. The change has just started and the building sector will have to deal with it more and more.

The lighting infrastructure is the ideal network not only to collect but also to distribute data (through LiFi communication, for instance). Since it is ubiquitous in (and around) buildings, it is possible to create a dense network of 'data points' in existing and requisite building infrastructure. If all luminaires would be equipped with sensors and emitters, this would offer a great potential for new applications.

The main questions, which are raised today (2019-2020) are:

1) Can these technologies lead to a reduction of energy consumption in buildings, through smarter management of electric lighting and solar shading systems?

2) Can these technologies offer opportunities to simplify installation and maintenance and reduce costs?

3) Can they provide added satisfaction to occupants?

4) Can they be robust (reduced failure rate) and usable for a long time (future-proof)?

\section{Interviews of professionals: opportunities and barriers}

\subsection{Construction of the survey in Denmark}

In order to explore how current available control systems are assessed, the Danish Building Research Institute at Aalborg University in Copenhagen (SBi-AAU) conducted a survey. In this survey, different solutions, strategies and aspects in relation to the lighting control systems had to be assessed. The survey was sent to different stakeholders of the industry, such as lighting professionals, lighting manufactures and project manager/client representatives. The survey was developed and distributed in Denmark, and was distributed later to other countries.

The aim of the survey was to identify the perception of the different possibilities of the current lighting control solutions and the expectations about the control systems. The survey aims to provide a mapping of the current lighting control systems available at the market and an overview of which functions are perceived as most important and which areas are found to be improved. Additionally, the findings of the survey could reveal aspects which could be most beneficial for later case studies.

Participants of the survey had to rank each question in relation to the perceived importance and the need for improvement. The ranking scale went from 1 to 3 , with 1 being very important and 3 being not important. The survey enclosed five general topics; energy, operational aspects, occupant control, occupant comfort and control functionality.

The question which was raised was: "What are, according to your opinion, the most important aspects of lighting controls and the topics
which need improvement?"

The results of the survey carried out in Denmark are provided in Table 1 in the Annex, where the respective numbers represent the amount of answers for each question. 


\section{Summary of questionnaire conducted in Denmark}

\section{Building managers / facility manager:}

The opportunities of reducing the energy consumption and of easy commissioning are found to be very important. These are also the areas of which they think that improvements are really needed. Automatic lighting control in relation to occupancy and daylight is found to be rather important together with the simplicity of operation.

However, the needs for improvements are not found that important. Most of the aspects are found to be of high or rather importance, while future proof concepts and initial cost issues are found less important. The potential for reduction of peak lighting electric power is not found important.

\section{Aspect related to occupants:}

Simplicity of operation is found to be the most important in relation to the occupant control and the some extend needs improvements. Automatic adjustment of illuminance and automatic lighting control per zone in the space is found important but are not found needs that much of improvements. Automatic adjustment of spectrum of light is not found to be that important but on the opposite needs improvements to a high extend. Manuel adjustment of spectrum of light and manual control per zone is not found important.

In relation to the occupant comfort the occupant's well-being is found to be of high importance and at the same time needs improvements. An acceptable operation and coverage area of occupancy sensors are to some degree found important and need improvements. Additionally, it is found important to maintain the view to the outside in relation to the shading systems. All aspects under occupant comfort are found important or rather important.

\section{Building owners / lease holders:}

Energy reduction and running cost are found important but only to some degree needed to be improved. User satisfaction in relation to reduce complains are found to be important and also rather important to be improved. Signal value of the building is not found important.

Control functionality:

Capability with other systems (BMS, HVAC etc.) is found to be important together with an open source protocol and both are found to a high extend needed to be improved. Automatic control of daylight and electric lighting together is also found important but a bit less needs of improvements. In opposite, geo-localization functionalities from luminaires, glare responsive control systems and DC supply for lighting is not found important.

\subsection{Extension of survey across the world}

\subsubsection{Organization}

After introducing the survey in Denmark, it was extended to other countries. The survey was sent out to IEA participants from the different participating countries. They were asked to distribute the survey to the stakeholders in their country. The survey was extended to China, Belgium, Poland, Norway and Austria. The survey distributed in the different countries is similar to the one developed in Denmark, and ratings are based on following question:

"What are, according to your opinion, the most important aspects of lighting controls and the topics which need improvement?"

\subsubsection{China}

The results of the survey distributed in China are provided in Table 2 in the Annex, where the respective numbers represent the amount of answers for each question. In China the total respondents are 57.

\section{Summary of questionnaire conducted in China}

\section{Building managers / facility manager:}

The possibility of energy reduction, low failure rate, simplicity of operation warranty, future proof concepts and standardization issues are found very important. All of the aspects in relation to the demand from building manager / facility manager are found to be of importance or rather important. None of the aspects are found to be not of importance. 
Aspect related to occupants:

Simplicity of operation and independent control of ambient and task lighting are found to be of high importance in relation to occupant control. The design quality of the interface, Capacity to override control system, Automatic lighting control per zone in the space, Personal control of lighting and shading from workplace are found to be rather of importance. Well-being and possibility to limit glare from windows are found to be of high importance in relation to occupant comfort. Smoothness of transition of lighting variations to avoid annoyance is found to be of rather importance. Capability of occupants to open shading systems automatic and manually is found rather important together with personal control of lighting and shading from workplace. Manual and automatic adjustment of spectrum of light is found less important.

\section{Building owners / lease holders:}

All the aspects are found to be of importance or rather of importance. Energy reduction and running cost are found of high importance together with reduced user complaints from users and future proof lighting systems. Green image and signal value of the building and the contribution of control system in relation to potential "green" certification are found rather important together with construction cost and clearly perceptible integration of daylighting and electric lighting.

Control functionality:

Compatibility with other systems (BMS, HVAC, etc.) is found to be important. Open source protocol of control system, automatic control of daylight and electric lighting together, daylight and glare responsive control and systems are found to be rather of importance together with override features for occupants and internet connection (grid connected systems). Wireless capabilities, DC supply for lighting and geo-localization functionalities from luminaires are found to be least important.

\subsubsection{Belgium}

The results of the survey distributed in Belgium are provided in Table 3 in the Annex, where the respective numbers represent the amount of answers for each question..

In Belgium the total respondents are seven.

\section{Summary of questionnaire conducted in Belgium}

\section{Building managers / facility manager:}

Potential for energy reduction and automatic lighting control related to occupancy (occupancy sensors) are found to be of high importance in relation to energy aspects. Automatic lighting control related to daylighting (daylightsensors), potential of shading system to maintain sufficient daylight penetration and potential for reduction of peak lighting electric power are found to be rather important. Potential of shading system to reduce heat gains is found to be of least importance. In relation to operational cost are most aspects found of rather importance were easy commissioning / re-commissioning / calibration, robustness / low failure rate, simplicity of operation (general management) are found to be slightly more important. Additional is mentioned, integration with BMS / other systems (at least HVAC, but also security, fire alarm emergency lighting, room reservation,...).

\section{Aspect related to occupants:}

Simplicity of operation (switches / interfaces) and manual adjustment of illuminance level are found to be of high importance in relation to occupant control. Automatic adjustment of spectrum of light and personal control of lighting and shading from workplace are found to be of least importance. In relation to occupant comfort possibility to limit glare from windows and well-being are found to be most important. Smoothness of transition of lighting variations to avoid annoyance is found to be of least importance.

\section{Building owners / lease holders:}

All the aspects are found to be of high or rather important. Energy reduction, clearly perceptible integration of daylighting and electric lighting and user satisfaction / reduced complaints from user are found to be of high importance. Additionally is mentioned energy consumption (real time and logbook function) monitoring and integration with other building technics (BACnet, loT, ...).

\section{Control functionality:}

The aspects in relation to control functionality are found to be of rather importance or less important. Automatic control of daylight and electric lighting together and override features for occupants are found to be of highest importance while geo-localization functionalities from luminaires, DC supply for lighting and glare responsive control systems are found to be least important. 


\subsubsection{Norway}

The results of the survey distributed in Norway are provided in Table 4 in the annex, where the respective numbers represent the amount of answers for each question.

In Norway the total respondents are four. The answers are presented with colour codes. When approximately $75 \%$ of a question is rated similar on the ranking scale it is marked with a grey colour and red when it is $100 \%$.

\section{Summary of questionnaire conducted in Norway}

Building managers / facility manager:

Potential of shading system to maintain sufficient daylight penetration is considered as the most important energy aspect while potential for reduction of lighting electricity consumption are rather important.

In relation to operational aspects the initial cost issues are considered to be very important while ongoing cost issues are found to be of less importance. Simplicity of operation are found to be of importance, while standardization issues and Quality labelling issues (R2S etc.) for new generation of controls are more or less not found to be of importance.

\section{Aspect related to occupants:}

In relation to occupant control it is found that the manual adjustment of illuminance level is of high importance and automatic adjustment of illuminance levels is considered as rather important. Aspects as simplicity of operation and the design quality of the interfaces are also found to be rather important.

Personal control of lighting and shading from workplace, manually switching possibility, i. g. in relation to the shading devices and capacity to override control system is of rather importance. In relation to occupant comfort the possibility to limit glare from windows is found to be of importance together with occupant's well-being. The smoothness of transition of lighting variations is found to be of little importance.

Building owners / lease holders:

Energy reduction, initial construction costs, a "green" image of the building and flexibility systems in relation to make them future proof to is found to be rather important while a clearly perceptible integration of daylighting and electric lighting is found of little importance.

\section{Control functionality:}

Compatibility with other systems (BMS, HVAC, etc.) and automatic control of daylight and electric lighting together are found rather important, while wireless capabilities are not found important at all. The new available technology opportunities are in general the area where least aspects are found important.

\subsubsection{Poland}

The results of the survey distributed in Poland are provided in Table 5 in the annex, where the respective numbers represent the amount of answers for each question.

In Poland the total respondents are 15 and distributed on following areas: Architects (14), Interior designer (1). The answers are presented with colour codes. When $50 \%$ to $75 \%$ of a question is rated similar on the ranking scale it is marked with a grey colour and red when it is above $75 \%$.

\section{Summary of questionnaire conducted in Poland}

\section{Building managers / facility manager:}

Potential for reduction of lighting electricity consumption is found to be rather important in relation to energy aspects. In relation to operational aspects initial and ongoing cost are found to be of rather importance together with robustness / low failure rate, simplicity of operation and warranty.

\section{Aspect related to occupants:}

Automatic adjustment of illuminance and personal control of lighting and shading from workplace are found of rather high importance in relation to occupant control.

In relation to occupant's comfort the user's psychological and physiological well-being is found of importance, hereunder the possibility to limit glare from windows and to limit unwanted heat gains. 
Building owners / lease holders:

Energy reduction is the only aspects which are found to be of rather importance.

\section{Control functionality:}

In relation to new technology opportunities available wireless capabilities and compatibility with other systems (BMS, HVAC, etc.) are found of rather important in combination with internet connection (grid connected systems) and combined light and heat control of shading.

\subsubsection{Austria}

The results of the survey distributed in Austria are provided in Table 6 in the annex, where the respective numbers represent the amount of answers for each question.

In Austria the total respondents are 12 and distributed on following areas: Sales Staff (2), Product Manager Automation (1), Representative sun shading association (1), Lighting Designers (2), Lighting Control Experts (2), Luminaire Development (1), Lighting Research (1), Building Owner (1) and Lease Holder (1). When $50 \%$ to $75 \%$ of a question is rated similar on the ranking scale it is marked with a grey colour and red when it is above $75 \%$.

\section{Summary of questionnaire conducted in Austria}

\section{Building managers / facility manager:}

The potential for reduction of lighting electricity consumption is found to be rather important in relation to energy aspects. However, the potential of shading systems to reduce heat gains and maintain sufficient daylight penetration together with automatic lighting control related to daylight and occupancy sensor are found to be more important. In relation to the operational aspects an easy commissioning, simplicity of operation, low failure rate of the system and future proof concepts in relation to ease long term maintenance and replacement of equipment is found to be very important. The initial and ongoing costs are found to be of rather importance together with flexibility of the system over longer term and standardization issues.

An easy commissioning, low failure rate, simplicity of operation together with a future proof concept are found to be most important in relation to the operational aspects.

The potential of shading system to maintain sufficient daylight, automatic lighting control related to daylight and future proof concepts are found to be in most need for improvements.

\section{Aspect related to occupants:}

Simplicity of operation is rated to be most important in relation to the occupant control together with a personal control of lighting and shading from workplace are found of rather high importance in relation to occupant control. Automatic adjustment of illuminance, manual switching possibility, independent control of task and ambient light and capability for the occupants to close shading systems are found to be of rather high importance.

The user's psychological and physiological well-being is found of importance and the possibility to limit glare from windows are found to be of most importance in relation to the occupant comfort.

Building owners / lease holders:

Energy reduction, initial construction costs, running costs and reduced complains from the users are found to be most important in relation to aspects of the building owners / lease holders.

\section{Control functionality:}

In relation to new technology opportunities available the combined light and heat control of shadings are found to be of high importance. The wireless capabilities and compatibility with other systems (BMS, HVAC, etc.) are found rather important in combination with internet connection (grid connected systems), automatic combined control of daylight and electric glare, responsive control systems and integration of other environmental sensors. 


\subsubsection{Sweden}

The results of the survey distributed in Sweden are provided in Table 7 in the annex, where the respective numbers represent the amount of answers for each question.

In Sweden, the total respondents are five for the first half part of the questionnaire while the last part is only answered by two and are representing following areas: Head of Lab in a building components manufacture, Head of Soft- and hardware development in a building components manufacture, Lighting Designer and Energy and Daylight Specialist. The answers are presented with colour codes. When approximately $60 \%$ to $80 \%$ of a question is rated similar on the ranking scale, it is marked with a grey colour and red when it is $100 \%$.

\section{Summary of questionnaire conducted in Sweden}

\section{Building managers / facility manager:}

The answers related to the importance of potential reduced lighting electricity consumption are divided between important and not important (two answered that it is important while three answered that it is not important). The simplicity of control system is found to be of high importance.

The results of the survey suggests, that it is important that the shading systems are able to reduce heat gains but that it is also possible to maintain a sufficient daylight penetration. All aspects in relation to future proof systems, flexibility of the system over long term, robustness / low failure rate and warranty / lifetime of the system is rated as important.

The findings suggest, that there is a need of improvements for daylight sensors for the automatic lighting control, easy commissioning and initial cost of lighting control systems.

\section{Aspect related to occupants:}

The possibility for the occupants to override the control system and that there is manual switching possibility is rated as important. The capability for the occupants to open and close shading system and at the same time to have the possibility to limit glare from windows and unwanted heat gains are found to be important. An independent control of ambient and task light and personal control of light and shading from work place are also rated as important together with the smoothness of transition of lighting variations in order to avoid annoyance is important. A manual adjustment of illuminance is found to be important while neither the automatic nor the manual adjustment of spectrum of light is found important.

Building owners / lease holders:

Only two answered this part of the survey, however, both answered that the energy reduction and initial construction cost is important.

Control functionality:

Only two answered this part of the survey, but answers suggest that open source protocol of control system, wireless capabilities and override features are important.

\subsubsection{Italy}

The results of the survey distributed in Italy are provided in Table 8 in the annex, where the respective numbers represent the amount of answers for each question.

In Italy the total respondents are three and are presenting following areas: Designer Maintenance in Electrotechnical industry and Sale in the Engineering Industry. The answers are presented with colour codes. When $50 \%$ to $75 \%$ of a question is rated similar on the ranking scale, it is marked with a grey colour and red when it is above $75 \%$.

\section{Summary of questionnaire conducted in Italy}

\section{Building managers / facility manager:}

From a building manager / facility manager's point of view are the potentials to save energy from the electric lighting and the automatic lighting control related to occupancy and daylight rated as important. Whereas the potential for reduction of peak lighting electric power, the potential of shading systems to reduce heat gains while maintaining a sufficient daylight penetration is neither found important nor unimportant. In relation to the 
operational aspects, future proof concepts are found important together with initial costs, while easy commissioning, a low failure rate and warranty / lifetime of the control system are found less important.

\section{Aspect related to occupants:}

In relation to the occupant control, the simplicity of the operation is rated as important, while the design quality of the interface and both manual and automatic adjustment of illuminance and spectrum of the light are found less important together with independent control of ambient and task light. However, the manual and automatic lighting control pr. zone are found to be important. The capacity to overrule the control is not found important. In relation to the occupant comfort, the possibility to limit glare from windows and the general well-being of the occupants are found important, while the possibility to reduce unwanted heat gain and an acceptable operation and coverage area of occupancy sensors are rated to be less important.

\section{Building owners / lease holders:}

In relation to the building owners, the possibility of energy reduction is rated as important, together with the initial and running costs. A clear perceptible integration of daylight, a "green" image of the building and the contribution of the control system to potential "green" certification are rated as less important. The signal value of the building / architectural aesthetics are not found to be of importance.

\section{Control functionality:}

An open source protocol of the control system and the integration of occupancy and other environmental sensors are rated as important. Wireless capabilities and internet connection (grid-connected system), combined light and heat control of shadings and override features for the occupants are rated as less important.

\subsubsection{Germany}

The results of the survey distributed in Germany are provided in Table 9 in the annex, where the respective numbers represent the amount of answers for each question.

\section{Summary of questionnaire conducted in Germany}

Building managers / facility manager:

From a building manager / facility manager's point of view, the energy aspects are found to be important. Also the possibility to control shading system in order to reduce heat gain and at the same time maintain sufficient daylight penetration are rated as important. In relation to the operational aspects, an easy commissioning, simplicity of operation, initial and ongoing cost issues are rated as important.

\section{Aspect related to occupants:}

In relation to the occupants, simplicity of operation of the lighting control system (interface/switches), manual adjustment of illuminance level and the possibility of manual switches are aspects rated as important. In addition, the possibility for the occupants to open and close the shading system and limit glare from windows are rated as important aspects. Independent control of ambient and task lighting and personal control of lighting and shading from the workplace are also rated as important together with the general psychological and physiological wellbeing of the occupants.

Building owners / lease holders:

Energy reduction, initial and ongoing cost. User satisfaction / reduced complaints from user and Future proof flexibility over long term.

\section{Control functionality:}

Compatibility with other systems (BMS, HVAC, etc.), automatic control of daylight and electric lighting together, daylight responsive control, combined light and heat control of shading. 


\section{Results and summary of the surveys}

The survey was conducted in nine countries: Denmark, China, Belgium, Norway, Poland, Austria, Sweden, Italy and Germany and showed some general tendencies. In general, all of the countries find the possibility of reducing electric lighting consumption very important, both from the building / facility manager and building owner / lease holder points of view.

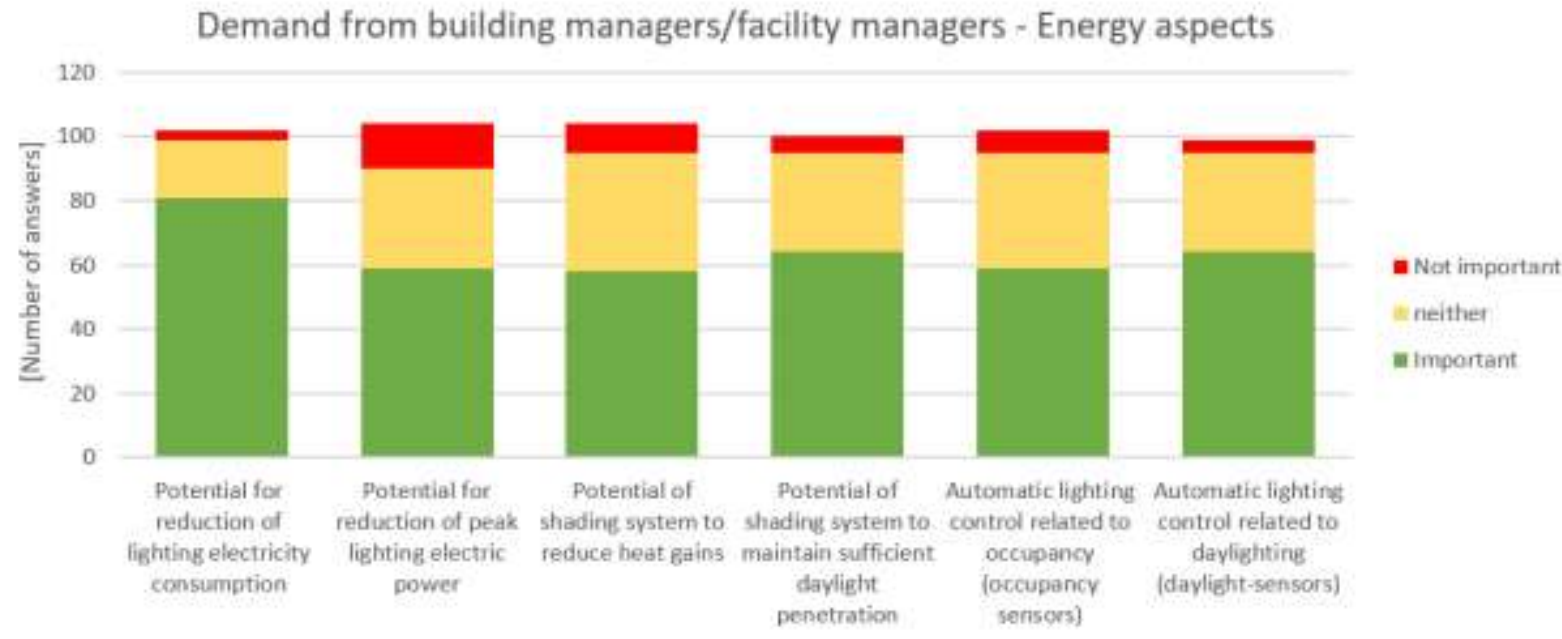

Figure 1. Answers from building / facility managers in relation to energy aspects.

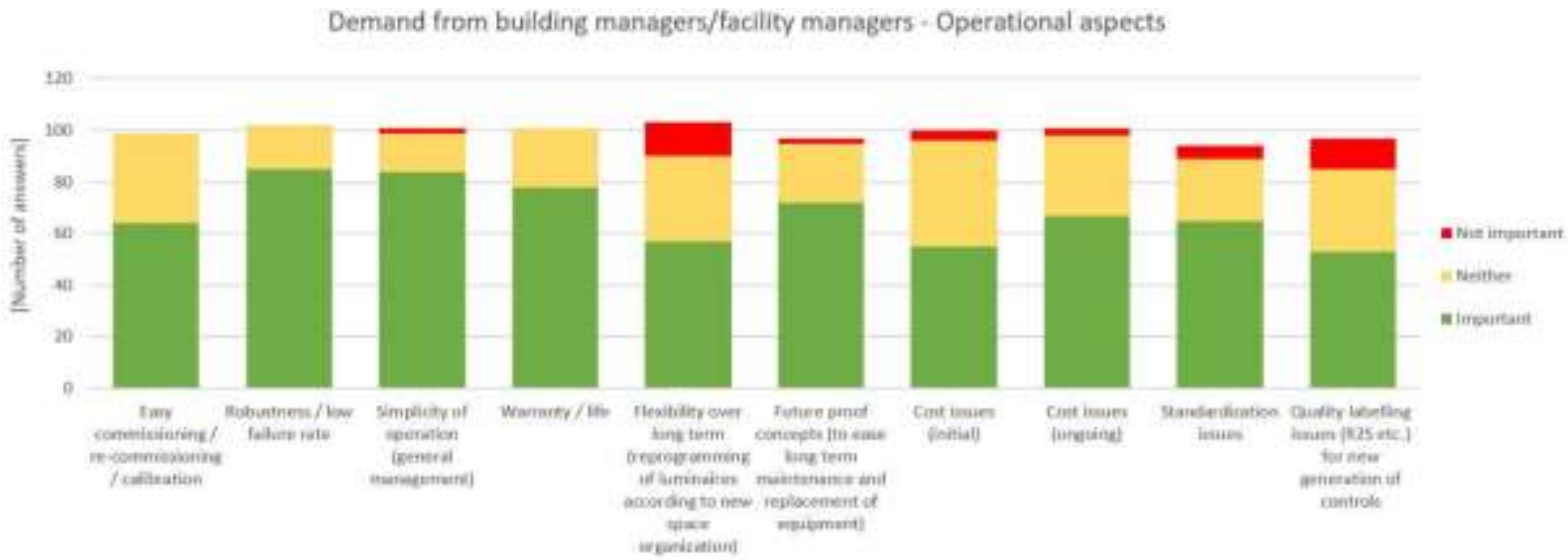

Figure 2. Answers from building / facility managers in relation to operational aspects.

In Denmark, an easy commissioning is found very important while the robustness of systems, low failure rate and warranty of the system are found more important in China and Poland. In Austria and Sweden, both an easy commissioning, robustness and low failure rate are found to be of high importance. Future proof concepts and standardization issues are found to be of high importance in China and Austria. In Poland, both initial and ongoing cost issues are found important in relation to building managers / facility managers while only the initial cost issues are found important in Norway. In Italy a future proof concept and initial cost issues are rated as to be most of importance. 


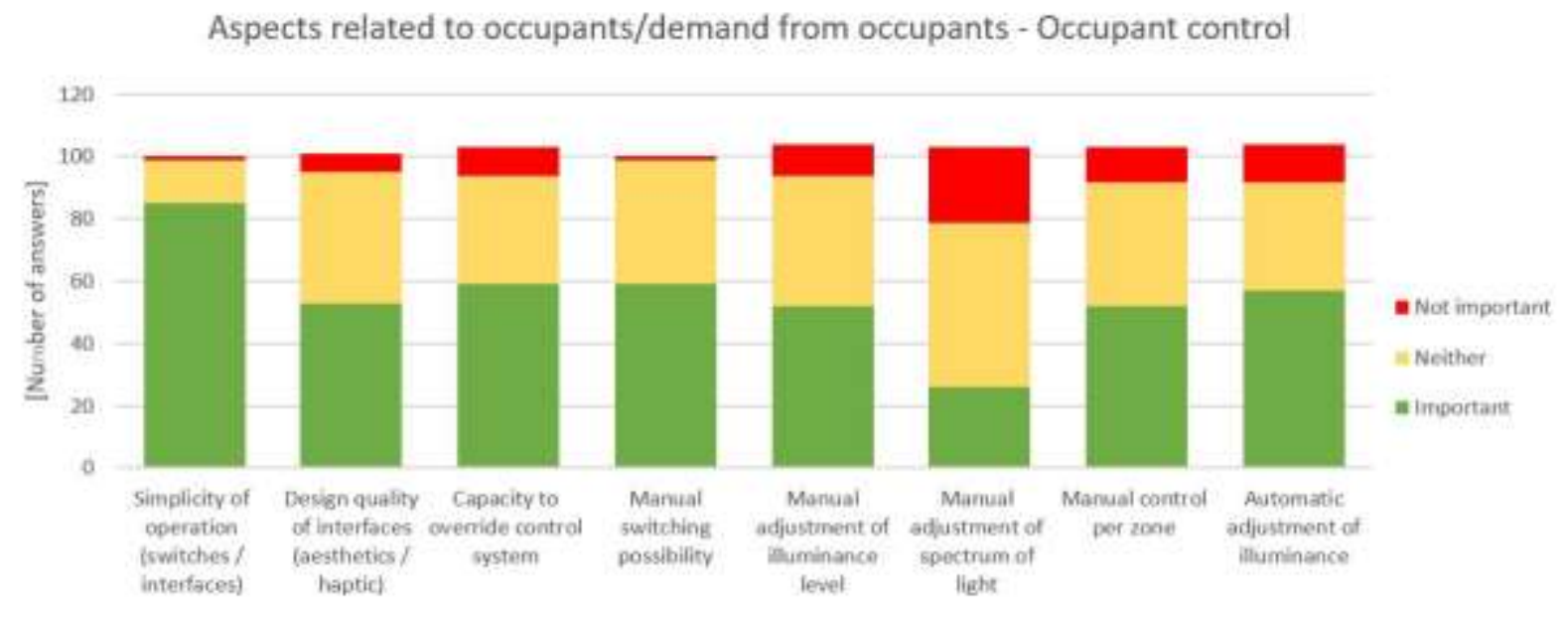

Figure 3. Answers from occupants / demand from occupants in relation to occupant control.

In relation to occupant controls, most of the countries find that simplicity of operation is very important. However, it is found less important in Norway and Poland (in Poland only half of participants find it important). All countries find the adjustments of illuminance important. Belgium and Norway find it most important to be able to control the illuminance manually, while Denmark and Poland find it most important with automatic adjustment of illuminance. None of the countries finds it of particular importance to be able to control the spectrum of light. In Sweden, a manual switching together with the capacity to override the control system is rated as important, while automatic lighting control related to occupancy and daylighting are rated as important in Italy together with automatic and manual lighting control pr. zone.

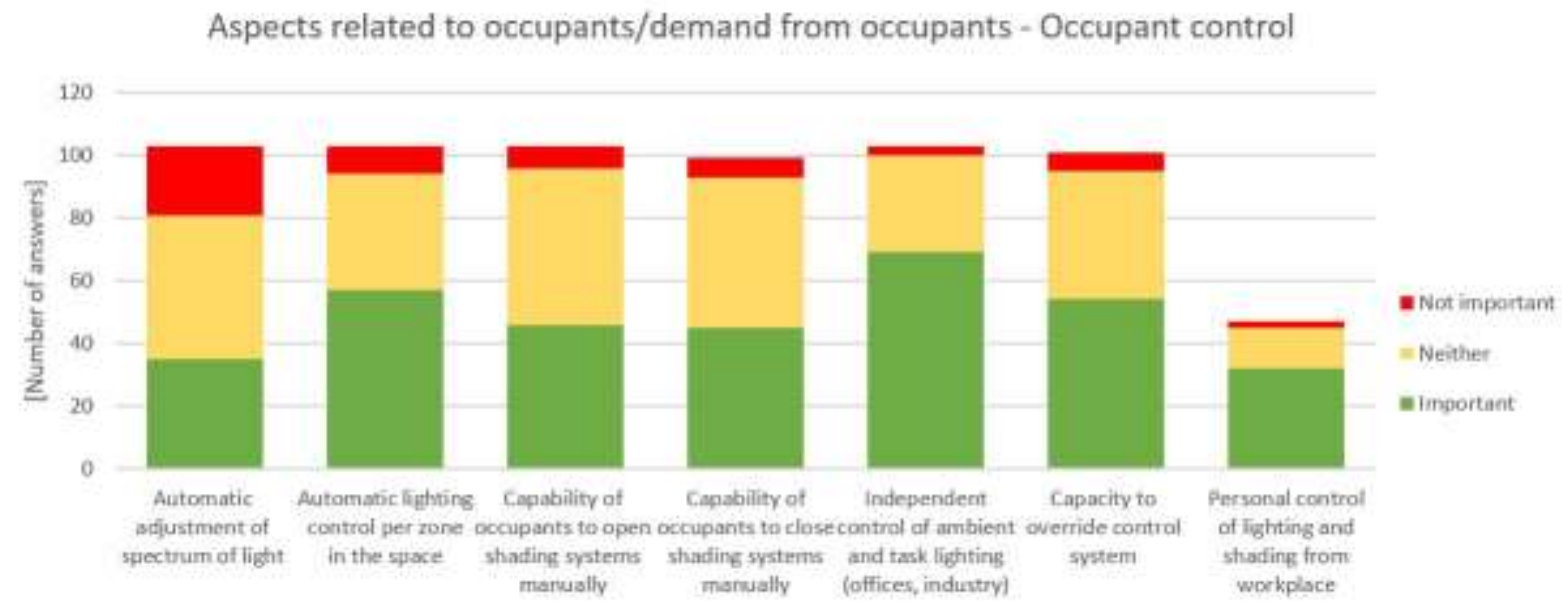

Figure 4. Answers from occupants / demand from occupants in relation to occupant control.

In Denmark, it is found of high importance with automatic lighting control per zone in the space. The survey suggests that it is of higher importance in Belgium, Poland and Austria to provide to the occupants the capabilities to close the shading systems manually and personal control of lighting and shading from the work place. The personal control of lighting and shading from work place is also rated as important in Sweden. Italy rates it as important with the possibility to limit glare from windows. China finds it of most importance with an independent control of ambient and task lighting. From the survey it appears that Norway does not find the occupant control possibilities of a very high importance. 


\section{Aspects related to occupants/demand from occupants - Occupant comfort}

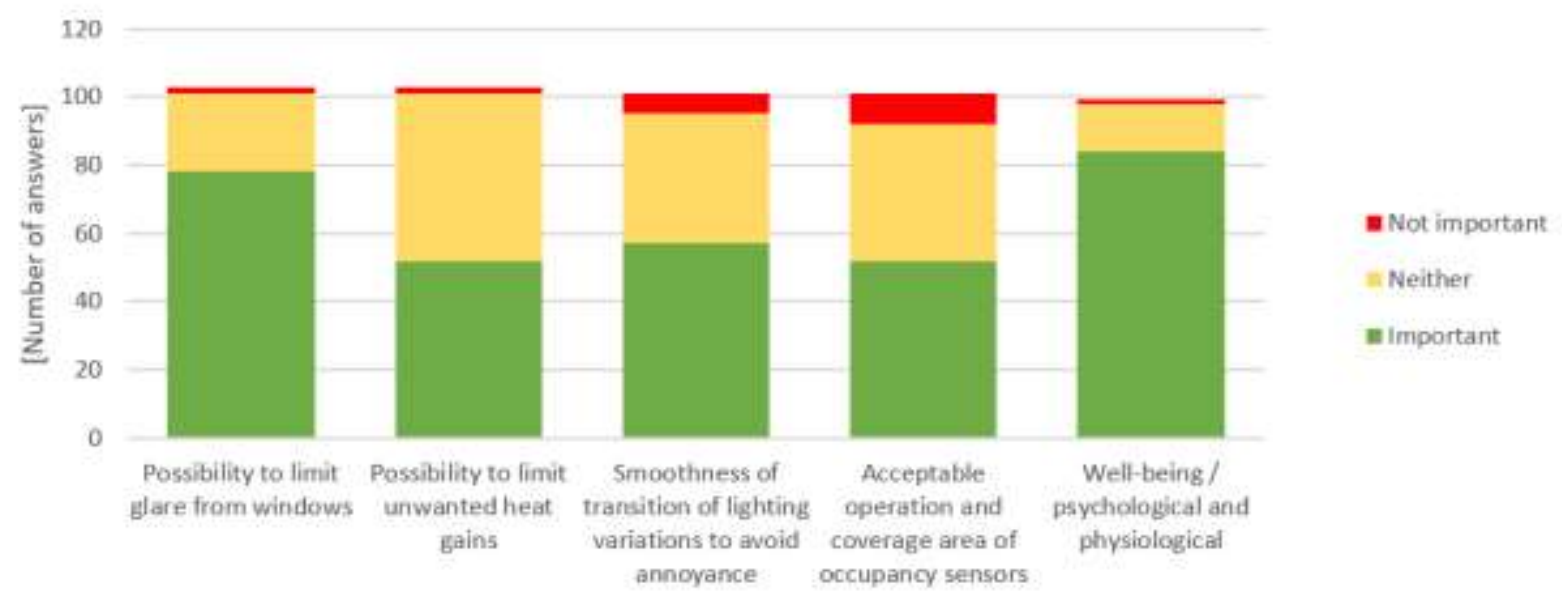

Figure 5. Answers from occupants / demand from occupants in relation to occupant comfort.

For China, Belgium, Poland and Austria it is of high importance to provide the possibility to limit glare from windows while neither Denmark nor Norway finds it of particular importance. The general well-being of the occupants is rated to be quite important for all countries. Denmark, China, Belgium and Austria rate in general the well-being to be of a slightly higher important than Norway and Poland. The same countries also find the user satisfaction and reduced complaints from users of highest importance seen from the building owners / lease holders' point of view. In Denmark, China and Austria the running cost is found of importance in relation to the building owners / leasers, while both initial and running costs are rated as important in Italy. China and Austria find it of high importance with a future proof system in relation to flexibility of the system over longer term.

\section{Aspects related to building owners/lease holders}

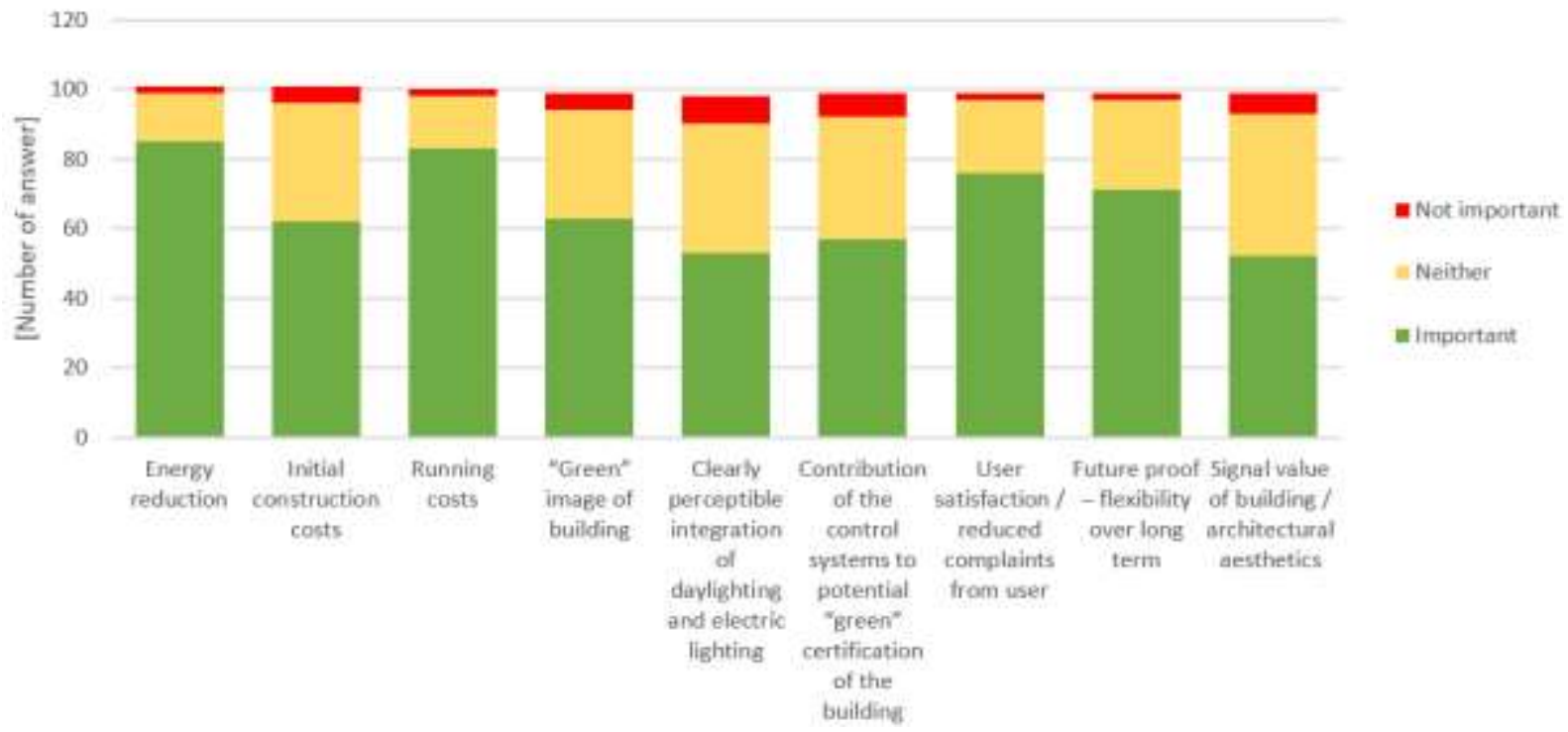

Figure 6. Answers from building owners / lease holders. 


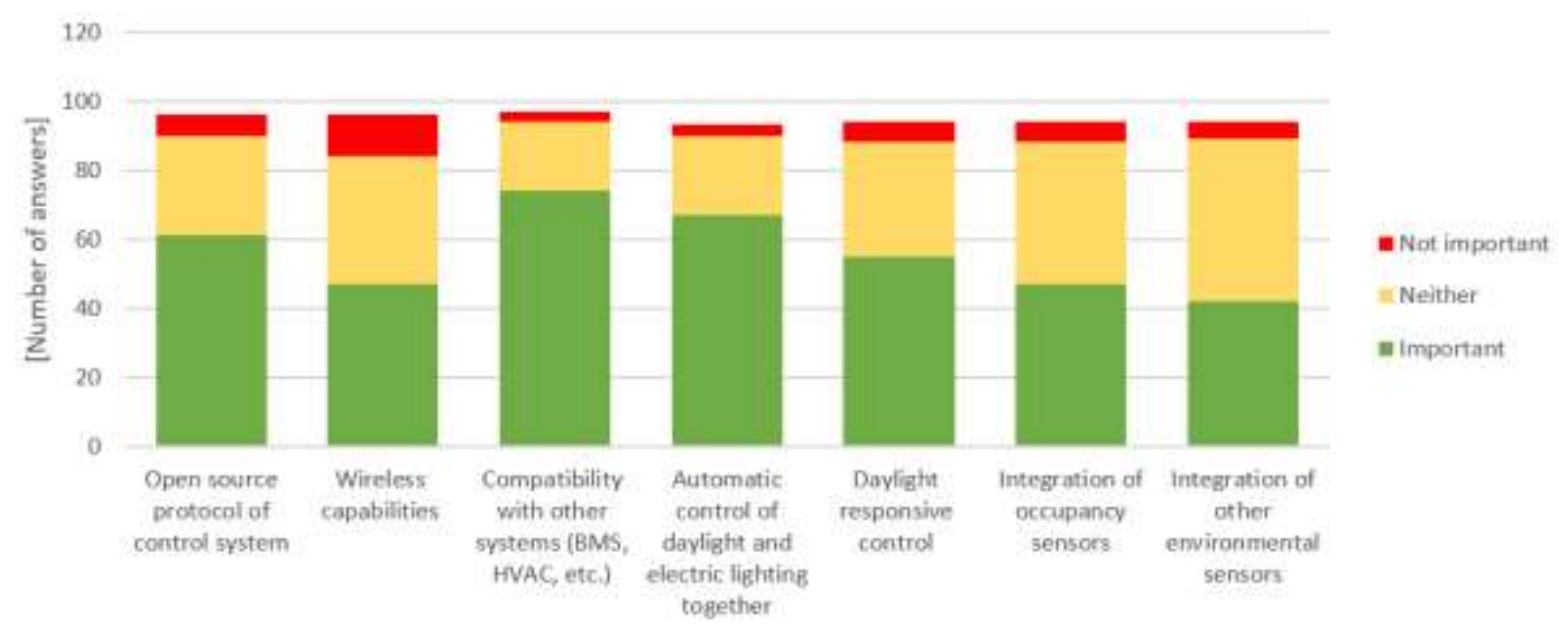

Figure 7. Answers from new technology opportunities available.

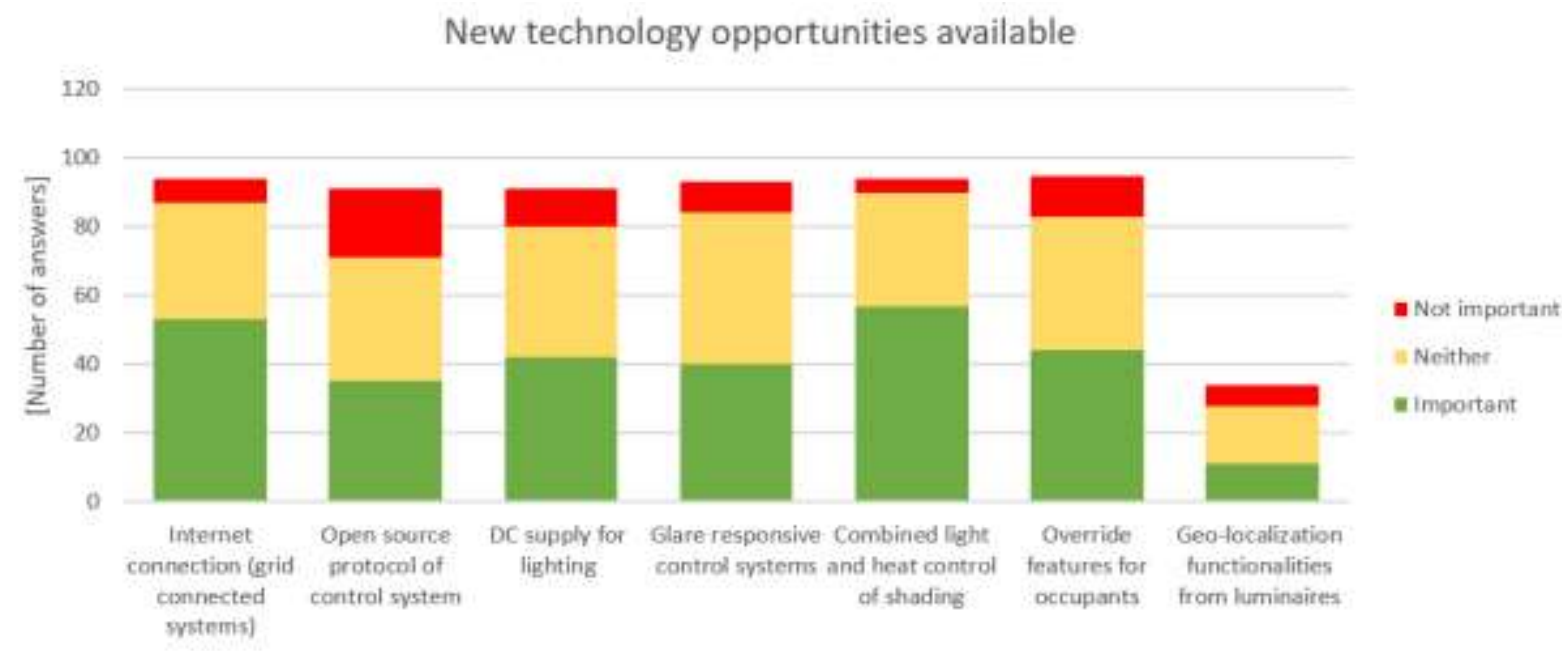

Figure 8. Answers from new technology opportunities available.

In relation to new technology opportunities available all countries find it important that the lighting system have compatibility with other systems (BMS, HVAC, etc.). Poland and Austria find it of high importance with wireless capabilities and internet connection (grid connected systems) of the lighting systems, while an open source protocol is rated as important in Denmark and Italy. Additional is an automatic combined control of daylight and electric light rated as important in Denmark and Italy, whereas Poland finds it of importance that the control system has a combined light and heat control of shading. Both automatic combined control of daylight and electric and combined light and heat control are found important in Austria.

In general, the conducted survey suggests that following aspects are rated to be of highest importance in relation to lighting control systems:

- Potential to reduce energy consumption from the electric light

- Well-being of the occupants

- Possibility to adjust the illuminance level (according to needs, manually or automatically)

- Possibility to reduce unwanted heat gains (according to needs, manually or automatically)

- Possibility to reduce glare from windows

- Possibility to open and close shading systems manually

- $\quad$ Simplicity of the control system (or user-interface, with possible overriding)

- Easy commissioning

- Future proof and flexibility of the system over long term 


\section{Discussion and Conclusion}

The findings from the summary suggest, that the two main reasons for the implementation of lighting control systems are:

1. The possibility to reduce the electric lighting consumptions and

2. The opportunity to increase the user's well-being and thereby reduce complaints from the users.

From a user perspective, this means that the lighting system must ensure visual acuity and comfort by providing a sufficient level of illuminance and the ability to regulate the light level. Always in relation to the task and the ambient light in the space, and thereby creating a pleasant and comfortable light environment.

Research suggests, when giving the users some manual control possibilities, the satisfaction with the lighting conditions in general increases The users should be able to both increase and dim the light levels or completely turn it off. This suggests, if the lighting control system is designed to regulate the illuminance automatically, it should be provided some kind of manual override. This is supported by the findings in the surveys, where all countries in one way or another find it important to provide the users with some possibility of user control.

In relation to the importance of user control, the findings additionally suggest, that the occupant control must be simple to operate. A control system which is easy for the users to understand intuitive, will most likely increase the chances of an 'optimal' interaction with the system. If the system does not meet the users need or is too complex to use, the possibility that the users will try to override the control systems increases, and this will most likely result in increased energy consumption.

Various options could be proposed to move from manual to automatic. For instance:

"After a manual overide, let the control system periodically prompt users with a message: your lighting control is on manual override presently; do you wish to stay in manual override, or do you wish the lighting control to switch back to automatic operation?"

After said message, if the user(s) do not react, the system will switch to automatic operation. Depending on the frequency of this proposed feature, this may indeed be experienced as a nuisance - but it will save energy for sure.

The predominant reason for installing lighting control systems is the possibility to reduce the energy consumption for electric lighting and to increase the user comfort to a certain degree. The latter being a growing concern.

Another way to state it, is that the target of reducing energy consumption of lighting cannot be done at the expense of occupant satisfaction, with poor quality of light (glare, flicker, low CRI, etc.).

This may explain why it is mainly found of importance to regulate (both automatically and manually) the illuminance levels and not the spectrum of light. This suggests, that the main purpose of the control system, is to regulate the illuminance levels based on the surrounding conditions such as the daylight availability. And only provide electric light, when needed, e. g. based on presence of occupants and daylight control.

It is also found from the survey, that it is desired to have some control of the shading system in relation to avoid glare from high daylight intensities and undesired solar radiation coming into the space. This increases the risk of overheating, resulting in an increased ventilation and/or cooling need leading to a higher energy use. However, in the two Scandinavian countries, it is found less important with the possibility to control the shadings in order to reduce glare from daylight and undesired heat transmission in the space. This may be due to the higher latitude and thereby a lower intensity of the daylight. 


\section{Annex}

\section{Questionnaire Tables}

Furthermore, colour codes are used to give a better insight in the results of the survey. When $50 \%$ to $75 \%$ of the answers to a question are rated equally, the cell is highlighted in grey. In case more than $75 \%$ of the answers are alike, the cell is highlighted in red.

\section{Questionnaire conducted in Denmark}

In Denmark, eight persons responded the survey. They are working on the following fields: Project manager / construction client representative (3), Lighting professionals (2), Lighting controls (1), Window manufacturer (1), Engineers (1).

Table 1. Results of survey conducted in Denmark.

\begin{tabular}{|c|c|c|c|c|c|c|}
\hline & $\begin{array}{l}\text { Ranking of importance: } \\
1=\text { very important to } 3 \text { not } \\
\text { important. }\end{array}$ & $\begin{array}{c}1 \\
\text { Important }\end{array}$ & 2 & $\begin{array}{c}3 \\
\text { Not } \\
\text { important }\end{array}$ & $\begin{array}{c}\text { Needs } \\
\text { improvement }\end{array}$ & $\begin{array}{l}\text { Does not need } \\
\text { improvement }\end{array}$ \\
\hline & $\begin{array}{l}\text { Demand from building } \\
\text { managers / facility managers }\end{array}$ & & & & & \\
\hline \multirow{6}{*}{ Energy aspects } & $\begin{array}{l}\text { Potential for reduction of } \\
\text { lighting electricity consumption }\end{array}$ & 8 & & & 6 & 1 \\
\hline & $\begin{array}{l}\text { Potential for reduction of peak } \\
\text { lighting electric power }\end{array}$ & 1 & 5 & 2 & 3 & 2 \\
\hline & $\begin{array}{l}\text { Potential of shading system to } \\
\text { reduce heat gains }\end{array}$ & 5 & 2 & 1 & 4 & 2 \\
\hline & $\begin{array}{l}\text { Potential of shading system to } \\
\text { maintain sufficient daylight } \\
\text { penetration }\end{array}$ & 6 & & 1 & 6 & \\
\hline & $\begin{array}{l}\text { Automatic lighting control } \\
\text { related to occupancy } \\
\text { (occupancy sensors) }\end{array}$ & 6 & 1 & & 5 & 2 \\
\hline & $\begin{array}{l}\text { Automatic lighting control } \\
\text { related to daylighting (daylight- } \\
\text { sensors) }\end{array}$ & 6 & 1 & & 6 & \\
\hline \multirow{6}{*}{$\begin{array}{l}\text { Operational } \\
\text { aspects }\end{array}$} & $\begin{array}{l}\text { Easy commissioning / re- } \\
\text { commissioning / calibration }\end{array}$ & 8 & & & 7 & \\
\hline & Robustness / low failure rate & 5 & 3 & & 1 & 4 \\
\hline & $\begin{array}{l}\text { Simplicity of operation (general } \\
\text { management) }\end{array}$ & 6 & 2 & & 1 & 4 \\
\hline & Warranty / life & 4 & 4 & & & 5 \\
\hline & $\begin{array}{l}\text { Flexibility over long term } \\
\text { (reprogramming of luminaires } \\
\text { according to new space } \\
\text { organization) }\end{array}$ & 5 & 2 & & 4 & 2 \\
\hline & $\begin{array}{l}\text { Future proof concepts (to ease } \\
\text { long term maintenance and } \\
\text { replacement of equipment) }\end{array}$ & 3 & 4 & & 5 & 1 \\
\hline
\end{tabular}




\begin{tabular}{|c|c|c|c|c|c|c|}
\hline & $\begin{array}{c}\text { Ranking of importance: } \\
1 \text { = very important to } 3 \text { not } \\
\text { important. }\end{array}$ & $\begin{array}{c}1 \\
\text { Important }\end{array}$ & 2 & $\begin{array}{c}3 \\
\text { Not } \\
\text { important } \\
\end{array}$ & $\begin{array}{c}\text { Needs } \\
\text { improvement }\end{array}$ & $\begin{array}{l}\text { Does not need } \\
\text { improvement }\end{array}$ \\
\hline & Cost issues (initial) & 3 & 4 & & 1 & 4 \\
\hline & Cost issues (ongoing) & 4 & 3 & & 2 & 3 \\
\hline & Standardization issues & 5 & 2 & & 4 & 2 \\
\hline & $\begin{array}{l}\text { Quality labelling issues (R2S } \\
\text { etc.) for new generation of } \\
\text { controls }\end{array}$ & & 4 & 2 & 2 & 3 \\
\hline \multirow[t]{2}{*}{$\begin{array}{l}\text { Additional } \\
\text { aspects you think } \\
\text { are important } \\
\text { (specify and rank) }\end{array}$} & & & & & & \\
\hline & $\begin{array}{l}\text { Aspects related to occupants / } \\
\text { demand from occupants }\end{array}$ & & & & & \\
\hline \multirow{15}{*}{ Occupant control } & $\begin{array}{l}\text { Simplicity of operation } \\
\text { (switches / interfaces) }\end{array}$ & 8 & & & 5 & 2 \\
\hline & $\begin{array}{l}\text { Design quality of interfaces } \\
\text { (aesthetics / haptic) }\end{array}$ & 3 & 4 & & 2 & 4 \\
\hline & $\begin{array}{l}\text { Capacity to override control } \\
\text { system }\end{array}$ & 2 & 6 & & 2 & 3 \\
\hline & Manual switching possibility & 5 & 3 & & 2 & 4 \\
\hline & $\begin{array}{l}\text { Manual adjustment of } \\
\text { illuminance level }\end{array}$ & 3 & 3 & 2 & 3 & 2 \\
\hline & $\begin{array}{l}\text { Manual adjustment of } \\
\text { spectrum of light }\end{array}$ & 1 & 3 & 3 & 3 & 2 \\
\hline & Manual control per zone & 1 & 6 & 1 & 2 & 3 \\
\hline & $\begin{array}{l}\text { Automatic adjustment of } \\
\text { illuminance }\end{array}$ & 8 & & & 5 & 1 \\
\hline & $\begin{array}{l}\text { Automatic adjustment of } \\
\text { spectrum of light }\end{array}$ & 4 & 3 & 1 & 7 & \\
\hline & $\begin{array}{l}\text { Automatic lighting control per } \\
\text { zone in the space }\end{array}$ & 7 & 1 & & 5 & 1 \\
\hline & $\begin{array}{l}\text { Capability of occupants to } \\
\text { open shading systems } \\
\text { manually }\end{array}$ & 6 & 1 & 1 & 2 & 3 \\
\hline & $\begin{array}{l}\text { Capability of occupants to } \\
\text { close shading systems } \\
\text { manually }\end{array}$ & 5 & 2 & 1 & 1 & 4 \\
\hline & $\begin{array}{l}\text { Independent control of ambient } \\
\text { and task lighting (offices, } \\
\text { industry) }\end{array}$ & 5 & 3 & & 4 & 1 \\
\hline & $\begin{array}{l}\text { Capacity to override control } \\
\text { system }\end{array}$ & 3 & 4 & 1 & 3 & 3 \\
\hline & $\begin{array}{l}\text { Personal control of lighting and } \\
\text { shading from workplace }\end{array}$ & 3 & 5 & & 2 & 3 \\
\hline \multirow{2}{*}{ Occupant comfort } & $\begin{array}{l}\text { Possibility to limit glare from } \\
\text { windows }\end{array}$ & 5 & 3 & & 4 & 2 \\
\hline & $\begin{array}{l}\text { Possibility to limit unwanted } \\
\text { heat gains }\end{array}$ & 5 & 3 & & 4 & 2 \\
\hline
\end{tabular}




\begin{tabular}{|c|c|c|c|c|c|c|}
\hline & $\begin{array}{l}\text { Ranking of importance: } \\
1=\text { very important to } 3 \text { not } \\
\text { important. }\end{array}$ & $\begin{array}{c}1 \\
\text { Important }\end{array}$ & 2 & $\begin{array}{c}3 \\
\text { Not } \\
\text { important }\end{array}$ & $\begin{array}{l}\text { Needs } \\
\text { improvement }\end{array}$ & $\begin{array}{l}\text { Does not need } \\
\text { improvement }\end{array}$ \\
\hline & $\begin{array}{l}\text { Smoothness of transition of } \\
\text { lighting variations to avoid } \\
\text { annoyance }\end{array}$ & 5 & 3 & & 5 & 2 \\
\hline & $\begin{array}{l}\text { Acceptable operation and } \\
\text { coverage area of occupancy } \\
\text { sensors }\end{array}$ & 6 & 2 & & 6 & 1 \\
\hline & $\begin{array}{l}\text { Well-being / psychological and } \\
\text { physiological }\end{array}$ & 8 & & & 7 & \\
\hline \multirow{12}{*}{$\begin{array}{l}\text { Additional } \\
\text { aspects you think } \\
\text { are important } \\
\text { (specify and rank) }\end{array}$} & $\begin{array}{l}\text { Maintain view to the outside } \\
\text { with shading system }\end{array}$ & & & & 1 & \\
\hline & $\begin{array}{l}\text { Aspects related to building } \\
\text { owners / lease holders }\end{array}$ & & & & & \\
\hline & Energy reduction & 7 & & & 6 & \\
\hline & Initial construction costs & 5 & 2 & & 3 & 1 \\
\hline & Running costs & 7 & & & 4 & 1 \\
\hline & "Green" image of building & 4 & 4 & & 5 & 1 \\
\hline & $\begin{array}{l}\text { Clearly perceptible integration } \\
\text { of daylighting and electric } \\
\text { lighting }\end{array}$ & 4 & 3 & 1 & 4 & 1 \\
\hline & $\begin{array}{l}\text { Contribution of the control } \\
\text { systems to potential "green" } \\
\text { certification of the building }\end{array}$ & 3 & 4 & 1 & 3 & 2 \\
\hline & $\begin{array}{l}\text { User satisfaction / reduced } \\
\text { complaints from user }\end{array}$ & 7 & 1 & & 6 & \\
\hline & $\begin{array}{l}\text { Future proof - flexibility over } \\
\text { long term }\end{array}$ & 5 & 2 & & 5 & \\
\hline & $\begin{array}{l}\text { Signal value of building / } \\
\text { architectural aesthetics }\end{array}$ & 2 & 4 & 1 & & 2 \\
\hline & $\begin{array}{l}\text { New technology opportunities } \\
\text { available }\end{array}$ & & & & & \\
\hline \multirow{8}{*}{$\begin{array}{l}\text { Control } \\
\text { functionality }\end{array}$} & $\begin{array}{l}\text { Open source protocol of } \\
\text { control system }\end{array}$ & 6 & 1 & & 7 & 1 \\
\hline & Wireless capabilities & 4 & 2 & 1 & 5 & 2 \\
\hline & $\begin{array}{l}\text { Compatibility with other } \\
\text { systems (BMS, HVAC, etc.) }\end{array}$ & 7 & & & 7 & \\
\hline & $\begin{array}{l}\text { Automatic control of daylight } \\
\text { and electric lighting together }\end{array}$ & 7 & & & 6 & \\
\hline & Daylight responsive control & 6 & 1 & & 4 & 2 \\
\hline & $\begin{array}{l}\text { Integration of occupancy } \\
\text { sensors }\end{array}$ & 4 & 2 & & 5 & 1 \\
\hline & $\begin{array}{l}\text { Integration of other } \\
\text { environmental sensors }\end{array}$ & 3 & 3 & & 6 & \\
\hline & $\begin{array}{l}\text { Internet connection (grid } \\
\text { connected systems) }\end{array}$ & 3 & 2 & 2 & 4 & 3 \\
\hline
\end{tabular}




\begin{tabular}{|c|c|c|c|c|c|c|}
\hline & $\begin{array}{l}\text { Ranking of importance: } \\
1=\text { very important to } 3 \text { not } \\
\text { important. }\end{array}$ & $\begin{array}{c}1 \\
\text { Important }\end{array}$ & 2 & $\begin{array}{c}3 \\
\text { Not } \\
\text { important }\end{array}$ & $\begin{array}{c}\text { Needs } \\
\text { improvement }\end{array}$ & $\begin{array}{l}\text { Does not need } \\
\text { improvement }\end{array}$ \\
\hline & $\begin{array}{l}\text { Open source protocol of } \\
\text { control system }\end{array}$ & 7 & & & 7 & \\
\hline & DC supply for lighting & 2 & 2 & 3 & 2 & 3 \\
\hline & $\begin{array}{l}\text { Glare responsive control } \\
\text { systems }\end{array}$ & 2 & 3 & 2 & 3 & 2 \\
\hline & $\begin{array}{l}\text { Combined light and heat } \\
\text { control of shading }\end{array}$ & 5 & 1 & & 7 & \\
\hline & $\begin{array}{l}\text { Override features for } \\
\text { occupants }\end{array}$ & 3 & 3 & 1 & 2 & 3 \\
\hline & $\begin{array}{l}\text { Geo-localization functionalities } \\
\text { from luminaires }\end{array}$ & 1 & 4 & 2 & 3 & 2 \\
\hline $\begin{array}{l}\text { Other } \\
\text { functionalities } \\
\text { associated with } \\
\text { lighting control } \\
\text { (specify) }\end{array}$ & $\begin{array}{l}\text { Danish Ministry of Defense } \\
\text { tries to avoid wireless controls }\end{array}$ & & & & & \\
\hline
\end{tabular}

\section{Questionnaire conducted in China}

Table 2. Results of survey conducted in China.

\begin{tabular}{|c|c|c|c|c|c|c|}
\hline & $\begin{array}{l}\text { Ranking of importance: } \\
1 \text { = very important to } 3 \text { not } \\
\text { important. }\end{array}$ & $\begin{array}{c}1 \\
\text { Important }\end{array}$ & 2 & $\begin{array}{c}3 \\
\text { Not } \\
\text { important }\end{array}$ & $\begin{array}{c}\text { Needs } \\
\text { improvement }\end{array}$ & $\begin{array}{l}\text { Does not need } \\
\text { improvement }\end{array}$ \\
\hline & $\begin{array}{l}\text { Demand from building } \\
\text { managers / facility } \\
\text { managers }\end{array}$ & & & & & \\
\hline \multirow{5}{*}{ Energy aspects } & $\begin{array}{l}\text { Potential for reduction of } \\
\text { lighting electricity } \\
\text { consumption }\end{array}$ & 44 & 13 & 0 & & \\
\hline & $\begin{array}{l}\text { Potential for reduction of } \\
\text { peak lighting electric } \\
\text { power }\end{array}$ & 39 & 15 & 3 & & \\
\hline & $\begin{array}{l}\text { Potential of shading } \\
\text { system to reduce heat } \\
\text { gains }\end{array}$ & 27 & 29 & 1 & & \\
\hline & $\begin{array}{l}\text { Potential of shading } \\
\text { system to maintain } \\
\text { sufficient daylight } \\
\text { penetration }\end{array}$ & 31 & 24 & 2 & & \\
\hline & $\begin{array}{l}\text { Automatic lighting control } \\
\text { related to occupancy } \\
\text { (occupancy sensors) }\end{array}$ & 30 & 23 & 4 & & \\
\hline
\end{tabular}




\begin{tabular}{|c|c|c|c|c|c|c|}
\hline & $\begin{array}{l}\text { Ranking of importance: } \\
1=\text { very important to } 3 \text { not } \\
\text { important. }\end{array}$ & $\begin{array}{c}1 \\
\text { Important }\end{array}$ & 2 & $\begin{array}{c}3 \\
\text { Not } \\
\text { important }\end{array}$ & $\begin{array}{c}\text { Needs } \\
\text { improvement }\end{array}$ & $\begin{array}{l}\text { Does not need } \\
\text { improvement }\end{array}$ \\
\hline & $\begin{array}{l}\text { Automatic lighting control } \\
\text { related to daylighting } \\
\text { (daylight-sensors) }\end{array}$ & 35 & 20 & 2 & & \\
\hline \multirow{10}{*}{$\begin{array}{l}\text { Operational } \\
\text { aspects }\end{array}$} & $\begin{array}{l}\text { Easy commissioning / re- } \\
\text { commissioning / } \\
\text { calibration }\end{array}$ & 32 & 25 & 0 & & \\
\hline & $\begin{array}{l}\text { Robustness / low failure } \\
\text { rate }\end{array}$ & 52 & 5 & 0 & & \\
\hline & $\begin{array}{l}\text { Simplicity of operation } \\
\text { (general management) }\end{array}$ & 46 & 10 & 1 & & \\
\hline & Warranty / life & 52 & 5 & 0 & & \\
\hline & $\begin{array}{l}\text { Flexibility over long term } \\
\text { (reprogramming of } \\
\text { luminaires according to } \\
\text { new space organization) }\end{array}$ & 30 & 22 & 5 & & \\
\hline & $\begin{array}{l}\text { Future proof concepts (to } \\
\text { ease long term } \\
\text { maintenance and } \\
\text { replacement of equipment) }\end{array}$ & 42 & 14 & 1 & & \\
\hline & Cost issues (initial) & 25 & 30 & 2 & & \\
\hline & Cost issues (ongoing) & 36 & 21 & 0 & & \\
\hline & Standardization issues & 44 & 12 & 1 & & \\
\hline & $\begin{array}{l}\text { Quality labelling issues } \\
\text { (R2S etc.) for new } \\
\text { generation of controls }\end{array}$ & 35 & 19 & 3 & & \\
\hline \multirow[t]{2}{*}{$\begin{array}{l}\text { Additional } \\
\text { aspects you } \\
\text { think are } \\
\text { important } \\
\text { (specify and } \\
\text { rank) }\end{array}$} & & & & & & \\
\hline & $\begin{array}{l}\text { Aspects related to } \\
\text { occupants / demand from } \\
\text { occupants }\end{array}$ & & & & & \\
\hline \multirow{7}{*}{$\begin{array}{l}\text { Occupant } \\
\text { control }\end{array}$} & $\begin{array}{l}\text { Simplicity of operation } \\
\text { (switches / interfaces) }\end{array}$ & 45 & 11 & 1 & & \\
\hline & $\begin{array}{l}\text { Design quality of } \\
\text { interfaces (aesthetics / } \\
\text { haptic) }\end{array}$ & 33 & 22 & 2 & & \\
\hline & $\begin{array}{l}\text { Capacity to override } \\
\text { control system }\end{array}$ & 36 & 19 & 2 & & \\
\hline & $\begin{array}{l}\text { Manual switching } \\
\text { possibility }\end{array}$ & 28 & 29 & 0 & & \\
\hline & $\begin{array}{l}\text { Manual adjustment of } \\
\text { illuminance level }\end{array}$ & 25 & 27 & 5 & & \\
\hline & $\begin{array}{l}\text { Manual adjustment of } \\
\text { spectrum of light }\end{array}$ & 14 & 34 & 9 & & \\
\hline & Manual control per zone & 27 & 26 & 4 & & \\
\hline
\end{tabular}




\begin{tabular}{|c|c|c|c|c|c|c|}
\hline & $\begin{array}{l}\text { Ranking of importance: } \\
1=\text { very important to } 3 \text { not } \\
\text { important. }\end{array}$ & $\begin{array}{c}1 \\
\text { Important }\end{array}$ & 2 & $\begin{array}{c}3 \\
\text { Not } \\
\text { important }\end{array}$ & $\begin{array}{c}\text { Needs } \\
\text { improvement }\end{array}$ & $\begin{array}{l}\text { Does not need } \\
\text { improvement }\end{array}$ \\
\hline & $\begin{array}{l}\text { Automatic adjustment of } \\
\text { illuminance }\end{array}$ & 25 & 26 & 6 & & \\
\hline & $\begin{array}{l}\text { Automatic adjustment of } \\
\text { spectrum of light }\end{array}$ & 20 & 31 & 6 & & \\
\hline & $\begin{array}{l}\text { Automatic lighting control } \\
\text { per zone in the space }\end{array}$ & 29 & 26 & 2 & & \\
\hline & $\begin{array}{l}\text { Capability of occupants to } \\
\text { open shading systems } \\
\text { manually }\end{array}$ & 14 & 39 & 4 & & \\
\hline & $\begin{array}{l}\text { Capability of occupants to } \\
\text { close shading systems } \\
\text { manually }\end{array}$ & 17 & 36 & 4 & & \\
\hline & $\begin{array}{l}\text { Independent control of } \\
\text { ambient and task lighting } \\
\text { (offices, industry) }\end{array}$ & 40 & 16 & 1 & & \\
\hline & $\begin{array}{l}\text { Personal control of lighting } \\
\text { and shading from } \\
\text { workplace }\end{array}$ & 32 & 23 & 2 & & \\
\hline \multirow{5}{*}{$\begin{array}{l}\text { Occupant } \\
\text { comfort }\end{array}$} & $\begin{array}{l}\text { Possibility to limit glare } \\
\text { from windows }\end{array}$ & 41 & 15 & 1 & & \\
\hline & $\begin{array}{l}\text { Possibility to limit } \\
\text { unwanted heat gains }\end{array}$ & 21 & 34 & 2 & & \\
\hline & $\begin{array}{l}\text { Smoothness of transition } \\
\text { of lighting variations to } \\
\text { avoid annoyance }\end{array}$ & 34 & 21 & 2 & & \\
\hline & $\begin{array}{l}\text { Acceptable operation and } \\
\text { coverage area of } \\
\text { occupancy sensors }\end{array}$ & 28 & 25 & 4 & & \\
\hline & $\begin{array}{l}\text { Well-being / psychological } \\
\text { and physiological }\end{array}$ & 44 & 13 & 0 & & \\
\hline \multirow[t]{8}{*}{$\begin{array}{l}\text { Additional } \\
\text { aspects you } \\
\text { think are } \\
\text { important } \\
\text { (specify and } \\
\text { rank) }\end{array}$} & & & & & & \\
\hline & $\begin{array}{l}\text { Aspects related to building } \\
\text { owners / lease holders }\end{array}$ & & & & & \\
\hline & Energy reduction & 45 & 11 & 1 & & \\
\hline & Initial construction costs & 31 & 23 & 3 & & \\
\hline & Running costs & 51 & 5 & 1 & & \\
\hline & "Green" image of building & 39 & 14 & 4 & & \\
\hline & $\begin{array}{l}\text { Clearly perceptible } \\
\text { integration of daylighting } \\
\text { and electric lighting }\end{array}$ & 30 & 23 & 4 & & \\
\hline & $\begin{array}{l}\text { Contribution of the control } \\
\text { systems to potential } \\
\text { "green" certification of the } \\
\text { building }\end{array}$ & 33 & 21 & 3 & & \\
\hline
\end{tabular}




\begin{tabular}{|c|c|c|c|c|c|c|}
\hline & $\begin{array}{l}\text { Ranking of importance: } \\
1=\text { very important to } 3 \text { not } \\
\text { important. }\end{array}$ & $\begin{array}{c}1 \\
\text { Important }\end{array}$ & 2 & $\begin{array}{c}3 \\
\text { Not } \\
\text { important }\end{array}$ & $\begin{array}{c}\text { Needs } \\
\text { improvement }\end{array}$ & $\begin{array}{c}\text { Does not need } \\
\text { improvement }\end{array}$ \\
\hline & $\begin{array}{l}\text { User satisfaction / reduced } \\
\text { complaints from user }\end{array}$ & 45 & 11 & 1 & & \\
\hline & $\begin{array}{l}\text { Future proof - flexibility } \\
\text { over long term }\end{array}$ & 41 & 16 & 0 & & \\
\hline & $\begin{array}{l}\text { Signal value of building / } \\
\text { architectural aesthetics }\end{array}$ & 33 & 23 & 1 & & \\
\hline \multirow[t]{2}{*}{$\begin{array}{l}\text { Additional } \\
\text { aspects you } \\
\text { think are } \\
\text { important } \\
\text { (specify and } \\
\text { rank) }\end{array}$} & & & & & & \\
\hline & $\begin{array}{l}\text { New technology } \\
\text { opportunities available }\end{array}$ & & & & & \\
\hline \multirow{13}{*}{$\begin{array}{l}\text { Control } \\
\text { functionality }\end{array}$} & $\begin{array}{l}\text { Open source protocol of } \\
\text { control system }\end{array}$ & 39 & 16 & 2 & & \\
\hline & Wireless capabilities & 21 & 28 & 8 & & \\
\hline & $\begin{array}{l}\text { Compatibility with other } \\
\text { systems (BMS, HVAC, } \\
\text { etc.) }\end{array}$ & 41 & 15 & 1 & & \\
\hline & $\begin{array}{l}\text { Automatic control of } \\
\text { daylight and electric } \\
\text { lighting together }\end{array}$ & 36 & 19 & 2 & & \\
\hline & $\begin{array}{l}\text { Daylight responsive } \\
\text { control }\end{array}$ & 30 & 24 & 3 & & \\
\hline & $\begin{array}{l}\text { Integration of occupancy } \\
\text { sensors }\end{array}$ & 27 & 28 & 2 & & \\
\hline & $\begin{array}{l}\text { Integration of other } \\
\text { environmental sensors }\end{array}$ & 20 & 34 & 3 & & \\
\hline & $\begin{array}{l}\text { Internet connection (grid } \\
\text { connected systems) }\end{array}$ & 35 & 20 & 2 & & \\
\hline & DC supply for lighting & 14 & 28 & 15 & & \\
\hline & $\begin{array}{l}\text { Glare responsive control } \\
\text { systems }\end{array}$ & 33 & 21 & 3 & & \\
\hline & $\begin{array}{l}\text { Combined light and heat } \\
\text { control of shading }\end{array}$ & 23 & 30 & 4 & & \\
\hline & $\begin{array}{l}\text { Override features for } \\
\text { occupants }\end{array}$ & 29 & 25 & 3 & & \\
\hline & $\begin{array}{l}\text { Geo-localization } \\
\text { functionalities from } \\
\text { luminaires }\end{array}$ & 22 & 26 & 9 & & \\
\hline $\begin{array}{l}\text { Other } \\
\text { functionalities } \\
\text { associated with } \\
\text { lighting control } \\
\text { (specify) }\end{array}$ & & & & & & \\
\hline
\end{tabular}




\section{Questionnaire conducted in Belgium}

In Belgium the questionnaire was answered as a five point scale but afterwards was transformed into a three point scale to be coherent with the assessment scale from the other countries. The five point scale was defined as a scale based on the assessment steps very important, rather important, neutral, not so important and not important at all. The scale is transformed from a five point scale to a three point scale by merging the very important and rather important into the statement important and the not so important and not important at all into not important.

Table 3. Results of Survey conducted in Belgium.

7 hits $(100 \%)$

5 and 6 hits ( > $70 \% \leq 85 \%)$

\begin{tabular}{|c|c|c|c|c|c|c|}
\hline & $\begin{array}{l}\text { Ranking of importance: } \\
1=\text { very important to } 3 \text { not } \\
\text { important. }\end{array}$ & $\begin{array}{c}1 \\
\text { Important }\end{array}$ & 2 & $\begin{array}{c}3 \\
\text { Not } \\
\text { important }\end{array}$ & $\begin{array}{c}\text { Needs } \\
\text { improvement }\end{array}$ & $\begin{array}{l}\text { Does not need } \\
\text { improvement }\end{array}$ \\
\hline & $\begin{array}{l}\text { Demand from building } \\
\text { managers / facility managers }\end{array}$ & & & & & \\
\hline \multirow{6}{*}{ Energy aspects } & $\begin{array}{l}\text { Potential for reduction of } \\
\text { lighting electricity consumption }\end{array}$ & 7 & & & 1 & 1 \\
\hline & $\begin{array}{l}\text { Potential for reduction of peak } \\
\text { lighting electric power }\end{array}$ & 6 & & 1 & 3 & \\
\hline & $\begin{array}{l}\text { Potential of shading system to } \\
\text { reduce heat gains }\end{array}$ & 4 & 1 & 2 & 1 & 1 \\
\hline & $\begin{array}{l}\text { Potential of shading system to } \\
\text { maintain sufficient daylight } \\
\text { penetration }\end{array}$ & 5 & 2 & & 2 & \\
\hline & $\begin{array}{l}\text { Automatic lighting control } \\
\text { related to occupancy } \\
\text { (occupancy sensors) }\end{array}$ & 7 & & & 1 & 1 \\
\hline & $\begin{array}{l}\text { Automatic lighting control } \\
\text { related to daylighting (daylight- } \\
\text { sensors) }\end{array}$ & 6 & 1 & & 2 & 1 \\
\hline \multirow{9}{*}{$\begin{array}{l}\text { Operational } \\
\text { aspects }\end{array}$} & $\begin{array}{l}\text { Easy commissioning / re- } \\
\text { commissioning / calibration }\end{array}$ & 6 & 1 & & 2 & \\
\hline & Robustness / low failure rate & 6 & 1 & & 1 & 1 \\
\hline & $\begin{array}{l}\text { Simplicity of operation (general } \\
\text { management) }\end{array}$ & 6 & & & 2 & 1 \\
\hline & Warranty / life & 5 & 1 & & 1 & \\
\hline & $\begin{array}{l}\text { Flexibility over long term } \\
\text { (reprogramming of luminaires } \\
\text { according to new space } \\
\text { organization) }\end{array}$ & 5 & & 2 & 2 & \\
\hline & $\begin{array}{l}\text { Future proof concepts (to ease } \\
\text { long term maintenance and } \\
\text { replacement of equipment) }\end{array}$ & 5 & 2 & & 2 & \\
\hline & Cost issues (initial) & 5 & 1 & 1 & 1 & 1 \\
\hline & Cost issues (ongoing) & 6 & & 1 & 2 & \\
\hline & Standardization issues & 4 & 1 & & 1 & \\
\hline
\end{tabular}




\begin{tabular}{|c|c|c|c|c|c|c|}
\hline & $\begin{array}{l}\text { Ranking of importance: } \\
1=\text { very important to } 3 \text { not } \\
\text { important. }\end{array}$ & $\begin{array}{c}1 \\
\text { Important }\end{array}$ & 2 & $\begin{array}{c}3 \\
\text { Not } \\
\text { important }\end{array}$ & $\begin{array}{c}\text { Needs } \\
\text { improvement }\end{array}$ & $\begin{array}{c}\text { Does not need } \\
\text { improvement }\end{array}$ \\
\hline & $\begin{array}{l}\text { Quality labelling issues (R2S } \\
\text { etc.) for new generation of } \\
\text { controls }\end{array}$ & 6 & 1 & & 1 & 1 \\
\hline \multirow[t]{2}{*}{$\begin{array}{l}\text { Additional aspects } \\
\text { you think are } \\
\text { important (specify } \\
\text { and rank) }\end{array}$} & $\begin{array}{l}\text { Integration with BMS / other } \\
\text { systems (at least HVAC, but } \\
\text { also security, fire alarm } \\
\text { emergency lighting, room } \\
\text { reservation,...) }\end{array}$ & 1 & & & 1 & \\
\hline & $\begin{array}{l}\text { Aspects related to occupants / } \\
\text { demand from occupants }\end{array}$ & & & & & \\
\hline \multirow{15}{*}{ Occupant control } & $\begin{array}{l}\text { Simplicity of operation } \\
\text { (switches / interfaces) }\end{array}$ & 7 & & & 1 & 1 \\
\hline & $\begin{array}{l}\text { Design quality of interfaces } \\
\text { (aesthetics / haptic) }\end{array}$ & 5 & 2 & & 1 & 1 \\
\hline & $\begin{array}{l}\text { Capacity to override control } \\
\text { system }\end{array}$ & 6 & & 1 & 2 & \\
\hline & Manual switching possibility & 6 & & 1 & 1 & 1 \\
\hline & $\begin{array}{l}\text { Manual adjustment of } \\
\text { illuminance level }\end{array}$ & 7 & & & 1 & 1 \\
\hline & $\begin{array}{l}\text { Manual adjustment of spectrum } \\
\text { of light }\end{array}$ & 3 & 2 & 2 & 1 & \\
\hline & Manual control per zone & 6 & & 1 & 1 & 1 \\
\hline & $\begin{array}{l}\text { Automatic adjustment of } \\
\text { illuminance }\end{array}$ & 5 & 1 & 2 & 1 & \\
\hline & $\begin{array}{l}\text { Automatic adjustment of } \\
\text { spectrum of light }\end{array}$ & 2 & 2 & 3 & 1 & \\
\hline & $\begin{array}{l}\text { Automatic lighting control per } \\
\text { zone in the space }\end{array}$ & 4 & 1 & 2 & 2 & \\
\hline & $\begin{array}{l}\text { Capability of occupants to open } \\
\text { shading systems manually }\end{array}$ & 6 & & 1 & 1 & 1 \\
\hline & $\begin{array}{l}\text { Capability of occupants to } \\
\text { close shading systems } \\
\text { manually }\end{array}$ & 6 & 1 & & 1 & 1 \\
\hline & $\begin{array}{l}\text { Independent control of ambient } \\
\text { and task lighting (offices, } \\
\text { industry) }\end{array}$ & 5 & & 1 & 1 & 1 \\
\hline & $\begin{array}{l}\text { Capacity to override control } \\
\text { system }\end{array}$ & 5 & 1 & 1 & 2 & \\
\hline & $\begin{array}{l}\text { Personal control of lighting and } \\
\text { shading from workplace }\end{array}$ & 3 & 3 & 1 & 1 & 1 \\
\hline \multirow{3}{*}{ Occupant comfort } & $\begin{array}{l}\text { Possibility to limit glare from } \\
\text { windows }\end{array}$ & 7 & & & 1 & 1 \\
\hline & $\begin{array}{l}\text { Possibility to limit unwanted } \\
\text { heat gains }\end{array}$ & 5 & 2 & & 1 & 1 \\
\hline & $\begin{array}{l}\text { Smoothness of transition of } \\
\text { lighting variations to avoid } \\
\text { annoyance }\end{array}$ & 3 & 2 & 1 & 2 & \\
\hline
\end{tabular}




\begin{tabular}{|c|c|c|c|c|c|c|}
\hline & $\begin{array}{l}\text { Ranking of importance: } \\
1=\text { very important to } 3 \text { not } \\
\text { important. }\end{array}$ & $\begin{array}{c}1 \\
\text { Important }\end{array}$ & 2 & $\begin{array}{c}3 \\
\text { Not } \\
\text { important }\end{array}$ & $\begin{array}{c}\text { Needs } \\
\text { improvement }\end{array}$ & $\begin{array}{l}\text { Does not need } \\
\text { improvement }\end{array}$ \\
\hline & $\begin{array}{l}\text { Acceptable operation and } \\
\text { coverage area of occupancy } \\
\text { sensors }\end{array}$ & 6 & 1 & & 1 & 1 \\
\hline & $\begin{array}{l}\text { Well-being / psychological and } \\
\text { physiological }\end{array}$ & 7 & & & 2 & \\
\hline \multirow[t]{11}{*}{$\begin{array}{l}\text { Additional aspects } \\
\text { you think are } \\
\text { important (specify } \\
\text { and rank) }\end{array}$} & $\begin{array}{l}\text { NO smoothness on daylight } \\
\text { control reaction of luminaires to } \\
\text { avoid the "illuminance sack", } \\
\text { that is really annoying. }\end{array}$ & 1 & & & 1 & \\
\hline & $\begin{array}{l}\text { Aspects related to building } \\
\text { owners / lease holders }\end{array}$ & & & & & \\
\hline & Energy reduction & 7 & & & 1 & 1 \\
\hline & Initial construction costs & 5 & 1 & 1 & & 2 \\
\hline & Running costs & 6 & 1 & & 2 & \\
\hline & "Green" image of building & 5 & 2 & & 1 & 1 \\
\hline & $\begin{array}{l}\text { Clearly perceptible integration } \\
\text { of daylighting and electric } \\
\text { lighting }\end{array}$ & 7 & & & 2 & \\
\hline & $\begin{array}{l}\text { Contribution of the control } \\
\text { systems to potential "green" } \\
\text { certification of the building }\end{array}$ & 6 & & & 2 & \\
\hline & $\begin{array}{l}\text { User satisfaction / reduced } \\
\text { complaints from user }\end{array}$ & 7 & & & 2 & \\
\hline & $\begin{array}{l}\text { Future proof - flexibility over } \\
\text { long term }\end{array}$ & 6 & 1 & & 2 & \\
\hline & $\begin{array}{l}\text { Signal value of building / } \\
\text { architectural aesthetics }\end{array}$ & 6 & 1 & & 1 & 1 \\
\hline \multirow[t]{3}{*}{$\begin{array}{l}\text { Additional aspects } \\
\text { you think are } \\
\text { important (specify } \\
\text { and rank) }\end{array}$} & $\begin{array}{l}\text { Energy consumption (real time } \\
\text { and logbook function) } \\
\text { monitoring }\end{array}$ & 1 & & & & \\
\hline & $\begin{array}{l}\text { Integration with other building } \\
\text { technics (BACnet, loT,...) }\end{array}$ & 1 & & & 1 & \\
\hline & $\begin{array}{l}\text { New technology opportunities } \\
\text { available }\end{array}$ & & & & & \\
\hline \multirow{7}{*}{$\begin{array}{l}\text { Control } \\
\text { functionality }\end{array}$} & $\begin{array}{l}\text { Open source protocol of control } \\
\text { system }\end{array}$ & 4 & 2 & & 2 & \\
\hline & Wireless capabilities & 5 & 1 & & 2 & 1 \\
\hline & $\begin{array}{l}\text { Compatibility with other } \\
\text { systems (BMS, HVAC, etc.) }\end{array}$ & 5 & 1 & & 2 & \\
\hline & $\begin{array}{l}\text { Automatic control of daylight } \\
\text { and electric lighting together }\end{array}$ & 6 & & & 2 & \\
\hline & Daylight responsive control & 5 & 1 & & 1 & 1 \\
\hline & $\begin{array}{l}\text { Integration of occupancy } \\
\text { sensors }\end{array}$ & 5 & & 1 & 1 & 1 \\
\hline & $\begin{array}{l}\text { Integration of other } \\
\text { environmental sensors }\end{array}$ & 5 & 1 & & 2 & \\
\hline
\end{tabular}




\begin{tabular}{|l|l|c|c|c|c|c|}
\hline & $\begin{array}{c}\text { Ranking of importance: } \\
\mathbf{1}=\text { very important to 3 not } \\
\text { important. }\end{array}$ & $\begin{array}{c}\mathbf{1} \\
\text { Important }\end{array}$ & $\mathbf{2}$ & $\begin{array}{c}\mathbf{3} \\
\text { Not } \\
\text { important }\end{array}$ & $\begin{array}{c}\text { Needs } \\
\text { improvement }\end{array}$ & $\begin{array}{c}\text { Does not need } \\
\text { improvement }\end{array}$ \\
\hline & $\begin{array}{l}\text { Internet connection (grid } \\
\text { connected systems) }\end{array}$ & 4 & 2 & & 2 & \\
\cline { 2 - 7 } & $\begin{array}{l}\text { Open source protocol of control } \\
\text { system }\end{array}$ & 4 & 1 & 1 & 1 & 1 \\
\cline { 2 - 7 } & DC supply for lighting & 3 & 2 & 1 & 1 & 1 \\
\cline { 2 - 7 } & $\begin{array}{l}\text { Glare responsive control } \\
\text { systems }\end{array}$ & 3 & 2 & & 2 & \\
\cline { 2 - 7 } & $\begin{array}{l}\text { Combined light and heat } \\
\text { control of shading }\end{array}$ & 5 & 1 & & & \\
\cline { 2 - 7 } & $\begin{array}{l}\text { Override features for } \\
\text { occupants }\end{array}$ & 6 & 3 & & & \\
\cline { 2 - 7 } & $\begin{array}{l}\text { Geo-localization functionalities } \\
\text { from luminaires }\end{array}$ & 3 & & & & \\
\hline $\begin{array}{l}\text { Other } \\
\text { functionalities } \\
\text { associated with } \\
\text { lighting control } \\
\text { (specify) }\end{array}$ & $\begin{array}{l}\text { Human Centric Lighting in } \\
\text { healthcare (both physical and } \\
\text { ssychological) }\end{array}$ & 1 & & & & \\
\hline
\end{tabular}

\section{Questionnaire conducted in Norway}

Table 4. Results of survey conducted in Norway.

$$
4 \text { hits (100\%) }
$$

\begin{tabular}{|c|c|c|c|c|c|c|}
\hline & $\begin{array}{c}\text { Ranking of importance: } \\
1 \text { = very important to } 3 \text { not } \\
\text { important. }\end{array}$ & $\begin{array}{c}1 \\
\text { Important }\end{array}$ & 2 & $\begin{array}{c}3 \\
\text { Not } \\
\text { important } \\
\end{array}$ & $\begin{array}{l}\text { Needs } \\
\text { improvement }\end{array}$ & $\begin{array}{c}\text { Does not } \\
\text { need } \\
\text { improvement } \\
\end{array}$ \\
\hline & $\begin{array}{l}\text { Demand from building } \\
\text { managers / facility managers }\end{array}$ & & & & & \\
\hline \multirow{6}{*}{ Energy aspects } & $\begin{array}{l}\text { Potential for reduction of } \\
\text { lighting electricity consumption }\end{array}$ & 3 & & & 1 & \\
\hline & $\begin{array}{l}\text { Potential for reduction of peak } \\
\text { lighting electric power }\end{array}$ & 2 & & 2 & 1 & 1 \\
\hline & $\begin{array}{l}\text { Potential of shading system to } \\
\text { reduce heat gains }\end{array}$ & 3 & 1 & & 1 & 1 \\
\hline & $\begin{array}{l}\text { Potential of shading system to } \\
\text { maintain sufficient daylight } \\
\text { penetration }\end{array}$ & 4 & & & 1 & \\
\hline & $\begin{array}{l}\text { Automatic lighting control } \\
\text { related to occupancy } \\
\text { (occupancy sensors) }\end{array}$ & 2 & 2 & & 2 & \\
\hline & $\begin{array}{l}\text { Automatic lighting control } \\
\text { related to daylighting (daylight- } \\
\text { sensors) }\end{array}$ & 2 & 1 & & 1 & \\
\hline $\begin{array}{l}\text { Operational } \\
\text { aspects }\end{array}$ & $\begin{array}{l}\text { Easy commissioning / re- } \\
\text { commissioning / calibration }\end{array}$ & 2 & 2 & & 1 & \\
\hline
\end{tabular}




\begin{tabular}{|c|c|c|c|c|c|c|}
\hline & $\begin{array}{l}\text { Ranking of importance: } \\
1=\text { very important to } 3 \text { not } \\
\text { important. }\end{array}$ & $\begin{array}{c}1 \\
\text { Important }\end{array}$ & 2 & $\begin{array}{c}3 \\
\text { Not } \\
\text { important }\end{array}$ & $\begin{array}{c}\text { Needs } \\
\text { improvement }\end{array}$ & $\begin{array}{c}\text { Does not } \\
\text { need } \\
\text { improvement }\end{array}$ \\
\hline & Robustness / low failure rate & 2 & 2 & & 1 & \\
\hline & $\begin{array}{l}\text { Simplicity of operation (general } \\
\text { management) }\end{array}$ & 3 & 1 & & 1 & \\
\hline & Warranty / life & & 3 & & & 1 \\
\hline & $\begin{array}{l}\text { Flexibility over long term } \\
\text { (reprogramming of luminaires } \\
\text { according to new space } \\
\text { organization) }\end{array}$ & 4 & & & 1 & \\
\hline & $\begin{array}{l}\text { Future proof concepts (to ease } \\
\text { long term maintenance and } \\
\text { replacement of equipment) }\end{array}$ & 2 & & & 1 & \\
\hline & Cost issues (initial) & 4 & & & 1 & \\
\hline & Cost issues (ongoing) & 2 & 2 & & 1 & \\
\hline & Standardization issues & 1 & 1 & & & 1 \\
\hline & $\begin{array}{l}\text { Quality labelling issues (R2S } \\
\text { etc.) for new generation of } \\
\text { controls }\end{array}$ & 1 & 1 & & 1 & \\
\hline \multicolumn{7}{|l|}{$\begin{array}{l}\text { Additional aspects } \\
\text { you think are } \\
\text { important (specify } \\
\text { and rank) }\end{array}$} \\
\hline & $\begin{array}{l}\text { Aspects related to occupants / } \\
\text { demand from occupants }\end{array}$ & & & & & \\
\hline \multirow{12}{*}{ Occupant control } & $\begin{array}{l}\text { Simplicity of operation } \\
\text { (switches / interfaces) }\end{array}$ & 3 & 1 & & 2 & \\
\hline & $\begin{array}{l}\text { Design quality of interfaces } \\
\text { (aesthetics / haptic) }\end{array}$ & 3 & & 1 & 1 & \\
\hline & $\begin{array}{l}\text { Capacity to override control } \\
\text { system }\end{array}$ & 3 & 1 & & 1 & \\
\hline & Manual switching possibility & 3 & 1 & & & 1 \\
\hline & $\begin{array}{l}\text { Manual adjustment of } \\
\text { illuminance level }\end{array}$ & 4 & & & 1 & \\
\hline & $\begin{array}{l}\text { Manual adjustment of } \\
\text { spectrum of light }\end{array}$ & 2 & 1 & 1 & 2 & \\
\hline & Manual control per zone & 2 & & 2 & 1 & \\
\hline & $\begin{array}{l}\text { Automatic adjustment of } \\
\text { illuminance }\end{array}$ & 3 & 1 & & 1 & \\
\hline & $\begin{array}{l}\text { Automatic adjustment of } \\
\text { spectrum of light }\end{array}$ & & 1 & 3 & & \\
\hline & $\begin{array}{l}\text { Automatic lighting control per } \\
\text { zone in the space }\end{array}$ & 2 & 1 & 1 & 1 & \\
\hline & $\begin{array}{l}\text { Capability of occupants to } \\
\text { open shading systems } \\
\text { manually }\end{array}$ & 3 & 1 & & 1 & \\
\hline & $\begin{array}{l}\text { Capability of occupants to } \\
\text { close shading systems } \\
\text { manually }\end{array}$ & 2 & 2 & & 1 & \\
\hline
\end{tabular}




\begin{tabular}{|c|c|c|c|c|c|c|}
\hline & $\begin{array}{l}\text { Ranking of importance: } \\
1 \text { = very important to } 3 \text { not } \\
\text { important. }\end{array}$ & $\begin{array}{c}1 \\
\text { Important }\end{array}$ & 2 & $\begin{array}{c}3 \\
\text { Not } \\
\text { important }\end{array}$ & $\begin{array}{l}\text { Needs } \\
\text { improvement }\end{array}$ & $\begin{array}{c}\text { Does not } \\
\text { need } \\
\text { improvement }\end{array}$ \\
\hline & $\begin{array}{l}\text { Independent control of ambient } \\
\text { and task lighting (offices, } \\
\text { industry) }\end{array}$ & 2 & 2 & & 1 & 1 \\
\hline & $\begin{array}{l}\text { Capacity to override control } \\
\text { system }\end{array}$ & 1 & 1 & & & 1 \\
\hline & $\begin{array}{l}\text { Personal control of lighting and } \\
\text { shading from workplace }\end{array}$ & 3 & 1 & & 2 & \\
\hline \multirow{5}{*}{ Occupant comfort } & $\begin{array}{l}\text { Possibility to limit glare from } \\
\text { windows }\end{array}$ & 3 & 1 & & 1 & \\
\hline & $\begin{array}{l}\text { Possibility to limit unwanted } \\
\text { heat gains }\end{array}$ & 2 & 2 & & 1 & \\
\hline & $\begin{array}{l}\text { Smoothness of transition of } \\
\text { lighting variations to avoid } \\
\text { annoyance }\end{array}$ & 1 & 2 & & 1 & \\
\hline & $\begin{array}{l}\text { Acceptable operation and } \\
\text { coverage area of occupancy } \\
\text { sensors }\end{array}$ & 1 & 1 & 2 & 1 & \\
\hline & $\begin{array}{l}\text { Well-being / psychological and } \\
\text { physiological }\end{array}$ & 3 & & 1 & 1 & \\
\hline \multirow[t]{11}{*}{$\begin{array}{l}\text { Additional aspects } \\
\text { you think are } \\
\text { important (specify } \\
\text { and rank) }\end{array}$} & & & & & & \\
\hline & $\begin{array}{l}\text { Aspects related to building } \\
\text { owners / lease holders }\end{array}$ & & & & & \\
\hline & Energy reduction & 3 & & & 1 & \\
\hline & Initial construction costs & 3 & & & & \\
\hline & Running costs & 2 & 1 & & & \\
\hline & "Green" image of building & 3 & 1 & & & \\
\hline & $\begin{array}{l}\text { Clearly perceptible integration } \\
\text { of daylighting and electric } \\
\text { lighting }\end{array}$ & 1 & 1 & 1 & & \\
\hline & $\begin{array}{l}\text { Contribution of the control } \\
\text { systems to potential "green" } \\
\text { certification of the building }\end{array}$ & 2 & 1 & & & \\
\hline & $\begin{array}{l}\text { User satisfaction / reduced } \\
\text { complaints from user }\end{array}$ & 2 & 1 & 1 & 1 & \\
\hline & $\begin{array}{l}\text { Future proof - flexibility over } \\
\text { long term }\end{array}$ & 3 & & 1 & 1 & \\
\hline & $\begin{array}{l}\text { Signal value of building / } \\
\text { architectural aesthetics }\end{array}$ & & 2 & 2 & 1 & \\
\hline \multirow[t]{2}{*}{$\begin{array}{l}\text { Additional aspects } \\
\text { you think are } \\
\text { important (specify } \\
\text { and rank) }\end{array}$} & & & & & & \\
\hline & $\begin{array}{l}\text { New technology opportunities } \\
\text { available }\end{array}$ & & & & & \\
\hline
\end{tabular}




\begin{tabular}{|c|c|c|c|c|c|c|}
\hline & $\begin{array}{l}\text { Ranking of importance: } \\
1=\text { very important to } 3 \text { not } \\
\text { important. }\end{array}$ & $\begin{array}{c}1 \\
\text { Important }\end{array}$ & 2 & $\begin{array}{c}3 \\
\text { Not } \\
\text { important }\end{array}$ & $\begin{array}{c}\text { Needs } \\
\text { improvement }\end{array}$ & $\begin{array}{c}\text { Does not } \\
\text { need } \\
\text { improvement }\end{array}$ \\
\hline \multirow{14}{*}{$\begin{array}{l}\text { Control } \\
\text { functionality }\end{array}$} & $\begin{array}{l}\text { Open source protocol of } \\
\text { control system }\end{array}$ & 2 & & 1 & 1 & \\
\hline & Wireless capabilities & & & 3 & 1 & \\
\hline & $\begin{array}{l}\text { Compatibility with other } \\
\text { systems (BMS, HVAC, etc.) }\end{array}$ & 3 & & 1 & 1 & \\
\hline & $\begin{array}{l}\text { Automatic control of daylight } \\
\text { and electric lighting together }\end{array}$ & 3 & & & & \\
\hline & Daylight responsive control & 1 & 2 & & $\begin{array}{l}\text { Not in every } \\
\text { room }\end{array}$ & \\
\hline & $\begin{array}{l}\text { Integration of occupancy } \\
\text { sensors }\end{array}$ & 1 & 1 & 1 & & \\
\hline & $\begin{array}{l}\text { Integration of other } \\
\text { environmental sensors }\end{array}$ & & 1 & 2 & & \\
\hline & $\begin{array}{l}\text { Internet connection (grid } \\
\text { connected systems) }\end{array}$ & & & 2 & discussible & \\
\hline & $\begin{array}{l}\text { Open source protocol of } \\
\text { control system }\end{array}$ & 1 & & 1 & & \\
\hline & DC supply for lighting & & & 1 & & \\
\hline & $\begin{array}{l}\text { Glare responsive control } \\
\text { systems }\end{array}$ & 1 & & 2 & & \\
\hline & $\begin{array}{l}\text { Combined light and heat } \\
\text { control of shading }\end{array}$ & 1 & & 1 & & \\
\hline & $\begin{array}{l}\text { Override features for } \\
\text { occupants }\end{array}$ & 2 & & & & \\
\hline & $\begin{array}{l}\text { Geo-localization functionalities } \\
\text { from luminaires }\end{array}$ & & 1 & 1 & & \\
\hline $\begin{array}{l}\text { Other } \\
\text { functionalities } \\
\text { associated with } \\
\text { lighting control } \\
\text { (specify) }\end{array}$ & & & & & & \\
\hline
\end{tabular}

\section{Questionnaire conducted in Poland}

Table 5. Results of survey conducted in Poland.

\begin{tabular}{|c|c|c|c|c|c|c|}
\hline & $>11(>75 \%)$ & & & $>7$ and $\leq 1$ & (> $50 \%$ and $\leq$ & $5 \%)$ \\
\hline & $\begin{array}{l}\text { Ranking of importance: } \\
1 \text { = very important to } 3 \text { not } \\
\text { important. }\end{array}$ & $\begin{array}{c}1 \\
\text { Important }\end{array}$ & 2 & $\begin{array}{c}3 \\
\text { Not } \\
\text { important }\end{array}$ & $\begin{array}{c}4 \\
\text { Needs } \\
\text { improvement }\end{array}$ & $\begin{array}{c}5 \\
\text { Does not } \\
\text { need } \\
\text { improvement }\end{array}$ \\
\hline & $\begin{array}{l}\text { Demand from building } \\
\text { managers / facility managers }\end{array}$ & & & & & \\
\hline \multirow{2}{*}{ Energy aspects $\mathrm{A}$} & $\begin{array}{l}\text { Potential for reduction of } \\
\text { lighting electricity consumption }\end{array}$ & 7 & 2 & & 5 & 1 \\
\hline & $\begin{array}{l}\text { Potential for reduction of peak } \\
\text { lighting electric power }\end{array}$ & 4 & 2 & 3 & 4 & 2 \\
\hline
\end{tabular}




\begin{tabular}{|c|c|c|c|c|c|c|}
\hline & $\begin{array}{l}\text { Ranking of importance: } \\
1 \text { = very important to } 3 \text { not } \\
\text { important. }\end{array}$ & $\begin{array}{c}1 \\
\text { Important }\end{array}$ & 2 & $\begin{array}{c}3 \\
\text { Not } \\
\text { important }\end{array}$ & $\begin{array}{c}4 \\
\text { Needs } \\
\text { improvement }\end{array}$ & $\begin{array}{c}5 \\
\text { Does not } \\
\text { need } \\
\text { improvement }\end{array}$ \\
\hline & $\begin{array}{l}\text { Potential of shading system to } \\
\text { reduce heat gains }\end{array}$ & 5 & 1 & 3 & 5 & \\
\hline & $\begin{array}{l}\text { Potential of shading system to } \\
\text { maintain sufficient daylight } \\
\text { penetration }\end{array}$ & 5 & 1 & 1 & 8 & \\
\hline & $\begin{array}{l}\text { Automatic lighting control } \\
\text { related to occupancy } \\
\text { (occupancy sensors) }\end{array}$ & 3 & 5 & 1 & 3 & 2 \\
\hline & $\begin{array}{l}\text { Automatic lighting control } \\
\text { related to daylighting (daylight- } \\
\text { sensors) }\end{array}$ & 4 & 4 & 1 & 5 & \\
\hline \multirow{10}{*}{$\begin{array}{l}\text { Operational } \\
\text { aspects } \\
\text { B }\end{array}$} & $\begin{array}{l}\text { Easy commissioning / re- } \\
\text { commissioning/ calibration }\end{array}$ & 3 & 5 & & 5 & \\
\hline & Robustness / low failure rate & 7 & 2 & & 4 & 1 \\
\hline & $\begin{array}{l}\text { Simplicity of operation (general } \\
\text { management) }\end{array}$ & 7 & 2 & & 6 & \\
\hline & Warranty / life & 8 & 1 & & 5 & \\
\hline & $\begin{array}{l}\text { Flexibility over long term } \\
\text { (reprogramming of luminaires } \\
\text { according to new space } \\
\text { organization) }\end{array}$ & 2 & 4 & 3 & 3 & 2 \\
\hline & $\begin{array}{l}\text { Future proof concepts (to ease } \\
\text { long term maintenance and } \\
\text { replacement of equipment) }\end{array}$ & 6 & 2 & 1 & 3 & 2 \\
\hline & Cost issues (initial) & 8 & 1 & & 6 & \\
\hline & Cost issues (ongoing) & 9 & & & 5 & \\
\hline & Standardization issues & 3 & 4 & 2 & 3 & 2 \\
\hline & $\begin{array}{l}\text { Quality labelling issues (R2S } \\
\text { etc.) for new generation of } \\
\text { controls }\end{array}$ & 4 & 2 & 3 & 3 & 2 \\
\hline \multirow[t]{2}{*}{$\begin{array}{l}\text { Additional aspects } \\
\text { you think are } \\
\text { important (specify } \\
\text { and rank) }\end{array}$} & & & & & & \\
\hline & $\begin{array}{l}\text { Aspects related to occupants / } \\
\text { demand from occupants }\end{array}$ & & & & & \\
\hline \multirow{6}{*}{ Occupant control } & $\begin{array}{l}\text { Simplicity of operation } \\
\text { (switches / interfaces) }\end{array}$ & 6 & 2 & & 5 & \\
\hline & $\begin{array}{l}\text { Design quality of interfaces } \\
\text { (aesthetics / haptic) }\end{array}$ & 4 & 4 & 1 & 2 & 2 \\
\hline & $\begin{array}{l}\text { Capacity to override control } \\
\text { system }\end{array}$ & 3 & 4 & 2 & 3 & 2 \\
\hline & Manual switching possibility & 4 & 4 & & 6 & \\
\hline & $\begin{array}{l}\text { Manual adjustment of } \\
\text { illuminance level }\end{array}$ & 3 & 5 & 1 & 5 & \\
\hline & $\begin{array}{l}\text { Manual adjustment of } \\
\text { spectrum of light }\end{array}$ & 4 & 3 & 2 & 3 & 2 \\
\hline
\end{tabular}




\begin{tabular}{|c|c|c|c|c|c|c|}
\hline & $\begin{array}{l}\text { Ranking of importance: } \\
1 \text { = very important to } 3 \text { not } \\
\text { important. }\end{array}$ & $\begin{array}{c}1 \\
\text { Important }\end{array}$ & 2 & $\begin{array}{c}3 \\
\text { Not } \\
\text { important }\end{array}$ & $\begin{array}{c}4 \\
\text { Needs } \\
\text { improvement }\end{array}$ & $\begin{array}{c}5 \\
\text { Does not } \\
\text { need } \\
\text { improvement }\end{array}$ \\
\hline & Manual control per zone & 6 & 2 & 1 & 3 & 2 \\
\hline & $\begin{array}{l}\text { Automatic adjustment of } \\
\text { illuminance }\end{array}$ & 7 & 1 & 1 & 4 & 2 \\
\hline & $\begin{array}{l}\text { Automatic adjustment of } \\
\text { spectrum of light }\end{array}$ & 5 & 3 & 1 & 3 & 2 \\
\hline & $\begin{array}{l}\text { Automatic lighting control per } \\
\text { zone in the space }\end{array}$ & 6 & 2 & 1 & 3 & 2 \\
\hline & $\begin{array}{l}\text { Capability of occupants to } \\
\text { open shading systems } \\
\text { manually }\end{array}$ & 5 & 4 & & 6 & \\
\hline & $\begin{array}{l}\text { Capability of occupants to } \\
\text { close shading systems } \\
\text { manually }\end{array}$ & 7 & 2 & & 6 & \\
\hline & $\begin{array}{l}\text { Independent control of ambient } \\
\text { and task lighting (offices, } \\
\text { industry) }\end{array}$ & 6 & 3 & & 5 & \\
\hline & $\begin{array}{l}\text { Capacity to override control } \\
\text { system }\end{array}$ & 4 & 5 & & 5 & \\
\hline & $\begin{array}{l}\text { Personal control of lighting and } \\
\text { shading from workplace }\end{array}$ & 9 & & & 6 & \\
\hline \multirow{5}{*}{ Occupant comfort } & $\begin{array}{l}\text { Possibility to limit glare from } \\
\text { windows }\end{array}$ & 7 & 2 & & 7 & \\
\hline & $\begin{array}{l}\text { Possibility to limit unwanted } \\
\text { heat gains }\end{array}$ & 8 & 1 & & 3 & 2 \\
\hline & $\begin{array}{l}\text { Smoothness of transition of } \\
\text { lighting variations to avoid } \\
\text { annoyance }\end{array}$ & 4 & 4 & 1 & 3 & 2 \\
\hline & $\begin{array}{l}\text { Acceptable operation and } \\
\text { coverage area of occupancy } \\
\text { sensors }\end{array}$ & 6 & 1 & 2 & 3 & 2 \\
\hline & $\begin{array}{l}\text { Well-being / psychological and } \\
\text { physiological }\end{array}$ & 9 & & & 6 & \\
\hline \multirow[t]{7}{*}{$\begin{array}{l}\text { Additional aspects } \\
\text { you think are } \\
\text { important (specify } \\
\text { and rank) }\end{array}$} & & & & & & \\
\hline & $\begin{array}{l}\text { Aspects related to building } \\
\text { owners / lease holders }\end{array}$ & & & & & \\
\hline & Energy reduction & 9 & & & 6 & \\
\hline & Initial construction costs & 5 & 4 & & 5 & \\
\hline & Running costs & 5 & 4 & & 5 & \\
\hline & "Green" image of building & 6 & 2 & 1 & 5 & 1 \\
\hline & $\begin{array}{l}\text { Clearly perceptible integration } \\
\text { of daylighting and electric } \\
\text { lighting }\end{array}$ & 5 & 3 & 1 & 3 & 2 \\
\hline
\end{tabular}




\begin{tabular}{|c|c|c|c|c|c|c|}
\hline & $\begin{array}{l}\text { Ranking of importance: } \\
1=\text { very important to } 3 \text { not } \\
\text { important. }\end{array}$ & $\begin{array}{c}1 \\
\text { Important }\end{array}$ & 2 & $\begin{array}{c}3 \\
\text { Not } \\
\text { important }\end{array}$ & $\begin{array}{c}4 \\
\text { Needs } \\
\text { improvement }\end{array}$ & $\begin{array}{c}5 \\
\text { Does not } \\
\text { need } \\
\text { improvement }\end{array}$ \\
\hline & $\begin{array}{l}\text { Contribution of the control } \\
\text { systems to potential "green" } \\
\text { certification of the building }\end{array}$ & 5 & 3 & 1 & 5 & 1 \\
\hline & $\begin{array}{l}\text { User satisfaction / reduced } \\
\text { complaints from user }\end{array}$ & 5 & 4 & & 5 & \\
\hline & $\begin{array}{l}\text { Future proof - flexibility over } \\
\text { long term }\end{array}$ & 6 & 2 & 1 & 4 & 1 \\
\hline & $\begin{array}{l}\text { Signal value of building / } \\
\text { architectural aesthetics }\end{array}$ & 6 & 3 & & 5 & 1 \\
\hline \multirow[t]{2}{*}{$\begin{array}{l}\text { Additional aspects } \\
\text { you think are } \\
\text { important (specify } \\
\text { and rank) }\end{array}$} & & & & & & \\
\hline & $\begin{array}{l}\text { New technology opportunities } \\
\text { available }\end{array}$ & & & & & \\
\hline \multirow{14}{*}{$\begin{array}{l}\text { Control } \\
\text { functionality }\end{array}$} & $\begin{array}{l}\text { Open source protocol of } \\
\text { control system }\end{array}$ & 2 & 5 & 2 & 4 & 1 \\
\hline & Wireless capabilities & 7 & 2 & & 6 & \\
\hline & $\begin{array}{l}\text { Compatibility with other } \\
\text { systems (BMS, HVAC, etc.) }\end{array}$ & 8 & 3 & & 5 & \\
\hline & $\begin{array}{l}\text { Automatic control of daylight } \\
\text { and electric lighting together }\end{array}$ & 6 & 2 & 1 & 5 & \\
\hline & Daylight responsive control & 4 & 3 & 2 & 4 & 1 \\
\hline & $\begin{array}{l}\text { Integration of occupancy } \\
\text { sensors }\end{array}$ & 3 & 5 & 1 & 5 & \\
\hline & $\begin{array}{l}\text { Integration of other } \\
\text { environmental sensors }\end{array}$ & 6 & 3 & & 3 & 2 \\
\hline & $\begin{array}{l}\text { Internet connection (grid } \\
\text { connected systems) }\end{array}$ & 7 & 2 & & 6 & \\
\hline & $\begin{array}{l}\text { Open source protocol of } \\
\text { control system }\end{array}$ & 5 & 3 & 1 & 5 & \\
\hline & DC supply for lighting & 4 & 4 & & 5 & \\
\hline & $\begin{array}{l}\text { Glare responsive control } \\
\text { systems }\end{array}$ & 4 & 4 & 1 & 4 & 1 \\
\hline & $\begin{array}{l}\text { Combined light and heat } \\
\text { control of shading }\end{array}$ & 7 & 2 & & 5 & \\
\hline & $\begin{array}{l}\text { Override features for } \\
\text { occupants }\end{array}$ & 4 & 5 & & 5 & \\
\hline & $\begin{array}{l}\text { Geo-localization functionalities } \\
\text { from luminaires }\end{array}$ & 5 & 4 & & 6 & \\
\hline $\begin{array}{l}\text { Other } \\
\text { functionalities } \\
\text { associated with } \\
\text { lighting control } \\
\text { (specify) }\end{array}$ & & & & & & \\
\hline
\end{tabular}




\section{Questionnaire conducted in Austria}

Table 6. Results of survey conducted in Austria.

$\geq 8(>75 \%)$

$\geq 6$ and $\leq 7(\geq 50 \%$ and $<75 \%)$

\begin{tabular}{|c|c|c|c|c|c|c|}
\hline & $\begin{array}{l}\text { Ranking of importance: } \\
1 \text { = very important to } 3 \text { not } \\
\text { important. }\end{array}$ & $\begin{array}{c}1 \\
\text { Important }\end{array}$ & 2 & $\begin{array}{c}3 \\
\text { Not } \\
\text { important }\end{array}$ & $\begin{array}{c}\text { Needs } \\
\text { improvement }\end{array}$ & $\begin{array}{c}\text { Does not } \\
\text { need } \\
\text { improvement }\end{array}$ \\
\hline & $\begin{array}{l}\text { Demand from building } \\
\text { managers / facility managers }\end{array}$ & & & & & \\
\hline \multirow{6}{*}{ Energy aspects } & $\begin{array}{l}\text { Potential for reduction of } \\
\text { lighting electricity } \\
\text { consumption }\end{array}$ & 7 & 3 & & 5 & 2 \\
\hline & $\begin{array}{l}\text { Potential for reduction of peak } \\
\text { lighting electric power }\end{array}$ & 4 & 5 & 1 & 5 & 2 \\
\hline & $\begin{array}{l}\text { Potential of shading system to } \\
\text { reduce heat gains }\end{array}$ & 8 & 1 & 1 & 5 & 2 \\
\hline & $\begin{array}{l}\text { Potential of shading system to } \\
\text { maintain sufficient daylight } \\
\text { penetration }\end{array}$ & 8 & 2 & & 7 & \\
\hline & $\begin{array}{l}\text { Automatic lighting control } \\
\text { related to occupancy } \\
\text { (occupancy sensors) }\end{array}$ & 8 & 2 & & 4 & 3 \\
\hline & $\begin{array}{l}\text { Automatic lighting control } \\
\text { related to daylighting } \\
\text { (daylight-sensors) }\end{array}$ & 8 & 2 & & 7 & \\
\hline \multirow{10}{*}{$\begin{array}{l}\text { Operational } \\
\text { aspects }\end{array}$} & $\begin{array}{l}\text { Easy commissioning / re- } \\
\text { commissioning / calibration }\end{array}$ & 10 & & & 6 & \\
\hline & Robustness / low failure rate & 9 & 1 & & 5 & 2 \\
\hline & $\begin{array}{l}\text { Simplicity of operation } \\
\text { (general management) }\end{array}$ & 10 & & & 6 & \\
\hline & Warranty / life & 5 & 5 & & 3 & 3 \\
\hline & $\begin{array}{l}\text { Flexibility over long term } \\
\text { (reprogramming of luminaires } \\
\text { according to new space } \\
\text { organization) }\end{array}$ & 7 & 2 & 1 & 5 & 1 \\
\hline & $\begin{array}{l}\text { Future proof concepts (to } \\
\text { ease long term maintenance } \\
\text { and replacement of } \\
\text { equipment) }\end{array}$ & 9 & 1 & & 7 & \\
\hline & Cost issues (initial) & 6 & 4 & & 5 & 2 \\
\hline & Cost issues (ongoing) & 7 & 3 & & 5 & 2 \\
\hline & Standardization issues & 6 & 3 & & 6 & \\
\hline & $\begin{array}{l}\text { Quality labelling issues (R2S } \\
\text { etc.) for new generation of } \\
\text { controls }\end{array}$ & 5 & 3 & 1 & 5 & 1 \\
\hline \multirow[t]{2}{*}{$\begin{array}{l}\text { Additional } \\
\text { aspects you think } \\
\text { are important } \\
\text { (specify and } \\
\text { rank) }\end{array}$} & $\begin{array}{l}\text { Integration with other building } \\
\text { controls (e.g. heating) }\end{array}$ & 1 & & & 1 & \\
\hline & $\begin{array}{l}\text { Aspects related to occupants } \\
\text { / demand from occupants }\end{array}$ & & & & & \\
\hline \multirow{3}{*}{ Occupant control } & $\begin{array}{l}\text { Simplicity of operation } \\
\text { (switches / interfaces) }\end{array}$ & 10 & & & 6 & \\
\hline & $\begin{array}{l}\text { Design quality of interfaces } \\
\text { (aesthetics / haptic) }\end{array}$ & 4 & 5 & 1 & 4 & 2 \\
\hline & $\begin{array}{l}\text { Capacity to override control } \\
\text { system }\end{array}$ & 4 & 3 & 2 & 4 & 2 \\
\hline
\end{tabular}




\begin{tabular}{|c|c|c|c|c|c|c|}
\hline & $\begin{array}{l}\text { Ranking of importance: } \\
1=\text { very important to } 3 \text { not } \\
\text { important. }\end{array}$ & $\begin{array}{c}1 \\
\text { Important }\end{array}$ & 2 & $\begin{array}{c}3 \\
\text { Not } \\
\text { important }\end{array}$ & $\begin{array}{c}\text { Needs } \\
\text { improvement }\end{array}$ & $\begin{array}{c}\text { Does not } \\
\text { need } \\
\text { improvement }\end{array}$ \\
\hline & Manual switching possibility & 6 & 3 & & 3 & 3 \\
\hline & $\begin{array}{l}\text { Manual adjustment of } \\
\text { illuminance level }\end{array}$ & 6 & 3 & 1 & 4 & 2 \\
\hline & $\begin{array}{l}\text { Manual adjustment of } \\
\text { spectrum of light }\end{array}$ & 2 & 5 & 3 & 3 & 3 \\
\hline & Manual control per zone & 6 & 3 & 1 & 3 & 3 \\
\hline & $\begin{array}{l}\text { Automatic adjustment of } \\
\text { illuminance }\end{array}$ & 7 & 3 & & 6 & \\
\hline & $\begin{array}{l}\text { Automatic adjustment of } \\
\text { spectrum of light }\end{array}$ & 4 & 4 & 2 & 5 & 1 \\
\hline & $\begin{array}{l}\text { Automatic lighting control per } \\
\text { zone in the space }\end{array}$ & 4 & 5 & 1 & 3 & 3 \\
\hline & $\begin{array}{l}\text { Capability of occupants to } \\
\text { open shading systems } \\
\text { manually }\end{array}$ & 5 & 4 & 1 & 1 & 5 \\
\hline & $\begin{array}{l}\text { Capability of occupants to } \\
\text { close shading systems } \\
\text { manually }\end{array}$ & 6 & 4 & & 3 & 3 \\
\hline & $\begin{array}{l}\text { Independent control of } \\
\text { ambient and task lighting } \\
\text { (offices, industry) }\end{array}$ & 6 & 3 & 1 & 2 & 4 \\
\hline & $\begin{array}{l}\text { Capacity to override control } \\
\text { system }\end{array}$ & 4 & 4 & 2 & 2 & 4 \\
\hline & $\begin{array}{l}\text { Personal control of lighting } \\
\text { and shading from workplace }\end{array}$ & 8 & 2 & & 5 & 1 \\
\hline \multirow{5}{*}{ Occupant comfort } & $\begin{array}{l}\text { Possibility to limit glare from } \\
\text { windows }\end{array}$ & 8 & 2 & & 5 & 1 \\
\hline & $\begin{array}{l}\text { Possibility to limit unwanted } \\
\text { heat gains }\end{array}$ & 7 & 3 & & 6 & \\
\hline & $\begin{array}{l}\text { Smoothness of transition of } \\
\text { lighting variations to avoid } \\
\text { annoyance }\end{array}$ & 6 & 4 & & 6 & \\
\hline & $\begin{array}{l}\text { Acceptable operation and } \\
\text { coverage area of occupancy } \\
\text { sensors }\end{array}$ & 3 & 5 & 1 & 5 & 1 \\
\hline & $\begin{array}{l}\text { Well-being / psychological } \\
\text { and physiological }\end{array}$ & 9 & 1 & & 7 & \\
\hline \multirow[t]{10}{*}{$\begin{array}{l}\text { Additional } \\
\text { aspects you think } \\
\text { are important } \\
\text { (specify and } \\
\text { rank) }\end{array}$} & & & & & & \\
\hline & $\begin{array}{l}\text { Aspects related to building } \\
\text { owners / lease holders }\end{array}$ & & & & & \\
\hline & Energy reduction & 8 & 3 & 1 & 6 & 1 \\
\hline & Initial construction costs & 8 & 3 & 1 & 7 & \\
\hline & Running costs & 8 & 3 & 1 & 6 & 1 \\
\hline & "Green" image of building & 5 & 5 & & 5 & 1 \\
\hline & $\begin{array}{l}\text { Clearly perceptible integration } \\
\text { of daylighting and electric } \\
\text { lighting }\end{array}$ & 6 & 3 & & 6 & 1 \\
\hline & $\begin{array}{l}\text { Contribution of the control } \\
\text { systems to potential "green" } \\
\text { certification of the building }\end{array}$ & 6 & 4 & & 6 & 1 \\
\hline & $\begin{array}{l}\text { User satisfaction / reduced } \\
\text { complaints from user }\end{array}$ & 8 & 2 & & 6 & 1 \\
\hline & $\begin{array}{l}\text { Future proof - flexibility over } \\
\text { long term }\end{array}$ & 7 & 3 & & 7 & \\
\hline
\end{tabular}




\begin{tabular}{|c|c|c|c|c|c|c|}
\hline & $\begin{array}{l}\text { Ranking of importance: } \\
1 \text { = very important to } 3 \text { not } \\
\text { important. }\end{array}$ & $\begin{array}{c}1 \\
\text { Important }\end{array}$ & 2 & $\begin{array}{c}3 \\
\text { Not } \\
\text { important }\end{array}$ & $\begin{array}{c}\text { Needs } \\
\text { improvement }\end{array}$ & $\begin{array}{c}\text { Does not } \\
\text { need } \\
\text { improvement }\end{array}$ \\
\hline & $\begin{array}{l}\text { Signal value of building / } \\
\text { architectural aesthetics }\end{array}$ & 5 & 5 & & 4 & 2 \\
\hline \multicolumn{7}{|l|}{$\begin{array}{l}\text { Additional } \\
\text { aspects you think } \\
\text { are important } \\
\text { (specify and } \\
\text { rank) }\end{array}$} \\
\hline & $\begin{array}{l}\text { New technology opportunities } \\
\text { available }\end{array}$ & & & & & \\
\hline \multirow{14}{*}{$\begin{array}{l}\text { Control } \\
\text { functionality }\end{array}$} & $\begin{array}{l}\text { Open source protocol of } \\
\text { control system }\end{array}$ & 4 & 4 & & 6 & \\
\hline & Wireless capabilities & 7 & 1 & & 7 & \\
\hline & $\begin{array}{l}\text { Compatibility with other } \\
\text { systems (BMS, HVAC, etc.) }\end{array}$ & 7 & 1 & & 6 & 1 \\
\hline & $\begin{array}{l}\text { Automatic control of daylight } \\
\text { and electric lighting together }\end{array}$ & 7 & 1 & & 5 & 1 \\
\hline & Daylight responsive control & 7 & 1 & & 5 & 1 \\
\hline & $\begin{array}{l}\text { Integration of occupancy } \\
\text { sensors }\end{array}$ & 4 & 3 & 1 & 3 & 3 \\
\hline & $\begin{array}{l}\text { Integration of other } \\
\text { environmental sensors }\end{array}$ & 6 & 2 & & 7 & \\
\hline & $\begin{array}{l}\text { Internet connection (grid } \\
\text { connected systems) }\end{array}$ & 3 & 4 & 1 & 6 & \\
\hline & $\begin{array}{l}\text { Open source protocol of } \\
\text { control system }\end{array}$ & 3 & 3 & & 5 & 1 \\
\hline & DC supply for lighting & & 6 & 2 & 5 & 1 \\
\hline & $\begin{array}{l}\text { Glare responsive control } \\
\text { systems }\end{array}$ & 6 & 2 & & 5 & 1 \\
\hline & $\begin{array}{l}\text { Combined light and heat } \\
\text { control of shading }\end{array}$ & 8 & & & 7 & \\
\hline & $\begin{array}{l}\text { Override features for } \\
\text { occupants }\end{array}$ & 4 & 4 & & 4 & 2 \\
\hline & $\begin{array}{l}\text { Geo-localization } \\
\text { functionalities from luminaires }\end{array}$ & 2 & 4 & 2 & 5 & 2 \\
\hline $\begin{array}{l}\text { Other } \\
\text { functionalities } \\
\text { associated with } \\
\text { lighting control } \\
\text { (specify) }\end{array}$ & Cloud connection & & 1 & & & \\
\hline
\end{tabular}

\section{Questionnaire conducted in Sweden}

Table 7. Results of Survey conducted in Sweden.

\begin{tabular}{|l|l|c|c|c|c|c|}
\hline & $\begin{array}{c}\text { Ranking of importance: } \\
\text { 1 = very important to 3 not } \\
\text { important. }\end{array}$ & $\begin{array}{c}\mathbf{1} \\
\text { Important }\end{array}$ & $\mathbf{2}$ & $\begin{array}{c}\mathbf{3} \\
\text { Not } \\
\text { important }\end{array}$ & $\begin{array}{c}\text { Needs } \\
\text { improvement }\end{array}$ & $\begin{array}{c}\text { Does not need } \\
\text { improvement }\end{array}$ \\
\hline \multirow{5}{*}{ Energy aspects } & $\begin{array}{l}\text { Demand from building } \\
\text { managers / facility managers }\end{array}$ & & & & & \\
\cline { 2 - 7 } & $\begin{array}{l}\text { Potential for reduction of } \\
\text { lighting electricity consumption }\end{array}$ & 2 & & 3 & & \\
\cline { 2 - 7 } & $\begin{array}{l}\text { Potential for reduction of peak } \\
\text { lighting electric power }\end{array}$ & 2 & 1 & 2 & & \\
\cline { 2 - 7 } & $\begin{array}{l}\text { Potential of shading system to } \\
\text { reduce heat gains }\end{array}$ & 4 & & 1 & & \\
\hline
\end{tabular}




\begin{tabular}{|c|c|c|c|c|c|c|}
\hline & $\begin{array}{l}\text { Ranking of importance: } \\
1=\text { very important to } 3 \text { not } \\
\text { important. }\end{array}$ & $\begin{array}{c}1 \\
\text { Important }\end{array}$ & 2 & $\begin{array}{c}3 \\
\text { Not } \\
\text { important }\end{array}$ & $\begin{array}{l}\text { Needs } \\
\text { improvement }\end{array}$ & $\begin{array}{l}\text { Does not need } \\
\text { improvement }\end{array}$ \\
\hline & $\begin{array}{l}\text { Potential of shading system to } \\
\text { maintain sufficient daylight } \\
\text { penetration }\end{array}$ & 3 & & 1 & 1 & \\
\hline & $\begin{array}{l}\text { Automatic lighting control } \\
\text { related to occupancy } \\
\text { (occupancy sensors) }\end{array}$ & 1 & 1 & 2 & 1 & \\
\hline & $\begin{array}{l}\text { Automatic lighting control } \\
\text { related to daylighting (daylight- } \\
\text { sensors) }\end{array}$ & 1 & & 1 & 3 & \\
\hline \multirow{10}{*}{$\begin{array}{l}\text { Operational } \\
\text { aspects }\end{array}$} & $\begin{array}{l}\text { Easy commissioning / re- } \\
\text { commissioning / calibration }\end{array}$ & 1 & & & 4 & \\
\hline & Robustness / low failure rate & 3 & & & 2 & \\
\hline & $\begin{array}{l}\text { Simplicity of operation (general } \\
\text { management) }\end{array}$ & 4 & & & 1 & \\
\hline & Warranty / life & 3 & 1 & & 1 & \\
\hline & $\begin{array}{l}\text { Flexibility over long term } \\
\text { (reprogramming of luminaires } \\
\text { according to new space } \\
\text { organization) }\end{array}$ & 3 & 1 & 1 & & \\
\hline & $\begin{array}{l}\text { Future proof concepts (to ease } \\
\text { long term maintenance and } \\
\text { replacement of equipment) }\end{array}$ & 3 & & & 2 & \\
\hline & Cost issues (initial) & 1 & 1 & & 3 & \\
\hline & Cost issues (ongoing) & 1 & 1 & 1 & 1 & 1 \\
\hline & Standardization issues & 2 & & 2 & 1 & \\
\hline & $\begin{array}{l}\text { Quality labelling issues (R2S } \\
\text { etc.) for new generation of } \\
\text { controls }\end{array}$ & 1 & 1 & 2 & 1 & \\
\hline \multirow[t]{2}{*}{$\begin{array}{l}\text { Additional aspects } \\
\text { you think are } \\
\text { important (specify } \\
\text { and rank) }\end{array}$} & $\begin{array}{l}\text { Integration with BMS / other } \\
\text { systems (at least HVAC, but } \\
\text { also security, fire alarm } \\
\text { emergency lighting, room } \\
\text { reservation,...) }\end{array}$ & & & & & \\
\hline & $\begin{array}{l}\text { Aspects related to occupants / } \\
\text { demand from occupants }\end{array}$ & & & & & \\
\hline \multirow{13}{*}{ Occupant control } & $\begin{array}{l}\text { Simplicity of operation (switches } \\
\text { / interfaces) }\end{array}$ & 2 & & & 2 & \\
\hline & $\begin{array}{l}\text { Design quality of interfaces } \\
\text { (aesthetics / haptic) }\end{array}$ & 1 & 2 & & 2 & \\
\hline & $\begin{array}{l}\text { Capacity to override control } \\
\text { system }\end{array}$ & 5 & & & & \\
\hline & Manual switching possibility & 5 & & & & \\
\hline & $\begin{array}{l}\text { Manual adjustment of } \\
\text { illuminance level }\end{array}$ & 3 & 2 & & & \\
\hline & $\begin{array}{l}\text { Manual adjustment of spectrum } \\
\text { of light }\end{array}$ & & 2 & 3 & & \\
\hline & Manual control per zone & 2 & 1 & 1 & 1 & \\
\hline & $\begin{array}{l}\text { Automatic adjustment of } \\
\text { illuminance }\end{array}$ & 1 & 1 & 2 & 1 & \\
\hline & $\begin{array}{l}\text { Automatic adjustment of } \\
\text { spectrum of light }\end{array}$ & & 1 & 3 & 1 & \\
\hline & $\begin{array}{l}\text { Automatic lighting control per } \\
\text { zone in the space }\end{array}$ & 2 & 1 & 1 & 1 & \\
\hline & $\begin{array}{l}\text { Capability of occupants to open } \\
\text { shading systems manually }\end{array}$ & 5 & & & & \\
\hline & $\begin{array}{l}\text { Capability of occupants to close } \\
\text { shading systems manually }\end{array}$ & 4 & 1 & & & \\
\hline & $\begin{array}{l}\text { Independent control of ambient } \\
\text { and task lighting (offices, } \\
\text { industry) }\end{array}$ & 4 & 1 & & & \\
\hline
\end{tabular}




\begin{tabular}{|c|c|c|c|c|c|c|}
\hline & $\begin{array}{l}\text { Ranking of importance: } \\
1=\text { very important to } 3 \text { not } \\
\text { important. }\end{array}$ & $\begin{array}{c}1 \\
\text { Important }\end{array}$ & 2 & $\begin{array}{c}3 \\
\text { Not } \\
\text { important }\end{array}$ & $\begin{array}{c}\text { Needs } \\
\text { improvement }\end{array}$ & $\begin{array}{l}\text { Does not need } \\
\text { improvement }\end{array}$ \\
\hline & $\begin{array}{l}\text { Personal control of lighting and } \\
\text { shading from workplace }\end{array}$ & 4 & 1 & & & \\
\hline \multirow{5}{*}{ Occupant comfort } & $\begin{array}{l}\text { Possibility to limit glare from } \\
\text { windows }\end{array}$ & 4 & & & 1 & \\
\hline & $\begin{array}{l}\text { Possibility to limit unwanted } \\
\text { heat gains }\end{array}$ & 3 & 1 & & 1 & \\
\hline & $\begin{array}{l}\text { Smoothness of transition of } \\
\text { lighting variations to avoid } \\
\text { annoyance }\end{array}$ & 3 & 1 & & 1 & \\
\hline & $\begin{array}{l}\text { Acceptable operation and } \\
\text { coverage area of occupancy } \\
\text { sensors }\end{array}$ & 2 & 2 & & 1 & \\
\hline & $\begin{array}{l}\text { Well-being / psychological and } \\
\text { physiological }\end{array}$ & 1 & & & & \\
\hline \multirow[t]{11}{*}{$\begin{array}{l}\text { Additional aspects } \\
\text { you think are } \\
\text { important (specify } \\
\text { and rank) }\end{array}$} & $\begin{array}{l}\text { The problem is in landscape } \\
\text { offices. Everyone has unique } \\
\text { visual needs. Landscape offices } \\
\text { are anyway very problematic as } \\
\text { work environments. }\end{array}$ & & & & & \\
\hline & $\begin{array}{l}\text { Aspects related to building } \\
\text { owners / lease holders }\end{array}$ & & & & & \\
\hline & Energy reduction & 2 & & & & \\
\hline & Initial construction costs & 2 & & & & \\
\hline & Running costs & 1 & & & 1 & \\
\hline & "Green" image of building & 1 & & & 1 & \\
\hline & $\begin{array}{l}\text { Clearly perceptible integration } \\
\text { of daylighting and electric } \\
\text { lighting }\end{array}$ & & 1 & & 1 & \\
\hline & $\begin{array}{l}\text { Contribution of the control } \\
\text { systems to potential "green" } \\
\text { certification of the building }\end{array}$ & 1 & & 1 & & \\
\hline & $\begin{array}{l}\text { User satisfaction / reduced } \\
\text { complaints from user }\end{array}$ & & 1 & & 1 & \\
\hline & $\begin{array}{l}\text { Future proof - flexibility over } \\
\text { long term }\end{array}$ & 1 & & & 1 & \\
\hline & $\begin{array}{l}\text { Signal value of building / } \\
\text { architectural aesthetics }\end{array}$ & & 1 & & 1 & \\
\hline \multirow[t]{2}{*}{$\begin{array}{l}\text { Additional aspects } \\
\text { you think are } \\
\text { important (specify } \\
\text { and rank) }\end{array}$} & & & & & & \\
\hline & $\begin{array}{l}\text { New technology opportunities } \\
\text { available }\end{array}$ & & & & & \\
\hline \multirow{10}{*}{$\begin{array}{l}\text { Control } \\
\text { functionality }\end{array}$} & $\begin{array}{l}\text { Open source protocol of control } \\
\text { system }\end{array}$ & 2 & & & & \\
\hline & Wireless capabilities & 2 & & & & \\
\hline & $\begin{array}{l}\text { Compatibility with other } \\
\text { systems (BMS, HVAC, etc.) }\end{array}$ & 1 & & & 1 & \\
\hline & $\begin{array}{l}\text { Automatic control of daylight } \\
\text { and electric lighting together }\end{array}$ & & 1 & & 1 & \\
\hline & Daylight responsive control & & 1 & & 1 & \\
\hline & $\begin{array}{l}\text { Integration of occupancy } \\
\text { sensors }\end{array}$ & 1 & & & 1 & \\
\hline & $\begin{array}{l}\text { Integration of other } \\
\text { environmental sensors }\end{array}$ & & 1 & & 1 & \\
\hline & $\begin{array}{l}\text { Internet connection (grid } \\
\text { connected systems) }\end{array}$ & 1 & & & 1 & \\
\hline & $\begin{array}{l}\text { Open source protocol of control } \\
\text { system }\end{array}$ & 1 & & & 1 & \\
\hline & DC supply for lighting & & 1 & 1 & & \\
\hline
\end{tabular}




\begin{tabular}{|l|l|c|c|c|c|c|}
\hline & \multicolumn{1}{|c|}{$\begin{array}{c}\text { Ranking of importance: } \\
\text { 1 = very important to 3 not } \\
\text { important. }\end{array}$} & $\begin{array}{c}\mathbf{1} \\
\text { Important }\end{array}$ & $\mathbf{2}$ & $\begin{array}{c}\text { 3 } \\
\text { Not } \\
\text { important }\end{array}$ & $\begin{array}{c}\text { Needs } \\
\text { improvement }\end{array}$ & $\begin{array}{c}\text { Does not need } \\
\text { improvement }\end{array}$ \\
\hline & $\begin{array}{l}\text { Glare responsive control } \\
\text { systems }\end{array}$ & & 1 & & 1 & \\
\cline { 2 - 6 } & $\begin{array}{l}\text { Combined light and heat control } \\
\text { of shading }\end{array}$ & 1 & 1 & & & \\
\cline { 2 - 7 } & Override features for occupants & 2 & & & & \\
\cline { 2 - 6 } & $\begin{array}{l}\text { Geo-localization functionalities } \\
\text { from luminaires }\end{array}$ & & 1 & 1 & & \\
\hline $\begin{array}{l}\text { Other } \\
\text { functionalities } \\
\text { associated with } \\
\text { lighting control } \\
\text { (specify) }\end{array}$ & & & & & & \\
\hline
\end{tabular}

\section{Questionnaire conducted in Italy}

Table 8. Results of survey conducted in Italy.

\begin{tabular}{|c|c|c|c|c|c|c|}
\hline & $\begin{array}{c}\text { Ranking of importance: } \\
\begin{array}{c}1=\text { very important to } 3 \text { not } \\
\text { important. }\end{array}\end{array}$ & $\begin{array}{c}1 \\
\text { Important }\end{array}$ & 2 & $\begin{array}{c}3 \\
\text { Not } \\
\text { important }\end{array}$ & $\begin{array}{c}\text { Needs } \\
\text { improvement }\end{array}$ & $\begin{array}{l}\text { Does not need } \\
\text { improvement }\end{array}$ \\
\hline & $\begin{array}{l}\text { Demand from building } \\
\text { managers / facility } \\
\text { managers }\end{array}$ & & & & & \\
\hline \multirow{6}{*}{ Energy aspects } & $\begin{array}{l}\text { Potential for reduction of } \\
\text { lighting electricity } \\
\text { consumption }\end{array}$ & 2 & & & 1 & \\
\hline & $\begin{array}{l}\text { Potential for reduction of } \\
\text { peak lighting electric power }\end{array}$ & 1 & 2 & & & \\
\hline & $\begin{array}{l}\text { Potential of shading } \\
\text { system to reduce heat } \\
\text { gains }\end{array}$ & 1 & 2 & & & \\
\hline & $\begin{array}{l}\text { Potential of shading } \\
\text { system to maintain } \\
\text { sufficient daylight } \\
\text { penetration }\end{array}$ & 1 & 2 & & & \\
\hline & $\begin{array}{l}\text { Automatic lighting control } \\
\text { related to occupancy } \\
\text { (occupancy sensors) }\end{array}$ & 2 & 1 & & & \\
\hline & $\begin{array}{l}\text { Automatic lighting control } \\
\text { related to daylighting } \\
\text { (daylight-sensors) }\end{array}$ & 2 & 1 & & & \\
\hline \multirow{5}{*}{$\begin{array}{l}\text { Operational } \\
\text { aspects }\end{array}$} & $\begin{array}{l}\text { Easy commissioning / re- } \\
\text { commissioning / calibration }\end{array}$ & 1 & 2 & & & \\
\hline & $\begin{array}{l}\text { Robustness / low failure } \\
\text { rate }\end{array}$ & 1 & 2 & & & \\
\hline & $\begin{array}{l}\text { Simplicity of operation } \\
\text { (general management) }\end{array}$ & 1 & & 1 & & \\
\hline & Warranty / life & 1 & 2 & & & \\
\hline & $\begin{array}{l}\text { Flexibility over long term } \\
\text { (reprogramming of }\end{array}$ & 1 & 1 & 1 & & \\
\hline
\end{tabular}




\begin{tabular}{|c|c|c|c|c|c|c|}
\hline & $\begin{array}{l}\text { Ranking of importance: } \\
1=\text { very important to } 3 \text { not } \\
\text { important. }\end{array}$ & $\begin{array}{c}1 \\
\text { Important }\end{array}$ & 2 & $\begin{array}{c}3 \\
\text { Not } \\
\text { important }\end{array}$ & $\begin{array}{l}\text { Needs } \\
\text { improvement }\end{array}$ & $\begin{array}{c}\text { Does not need } \\
\text { improvement }\end{array}$ \\
\hline & $\begin{array}{l}\text { luminaires according to } \\
\text { new space organization) }\end{array}$ & & & & & \\
\hline & $\begin{array}{l}\text { Future proof concepts (to } \\
\text { ease long term } \\
\text { maintenance and } \\
\text { replacement of equipment) }\end{array}$ & 2 & & & & 1 \\
\hline & Cost issues (initial) & 2 & & 1 & & \\
\hline & Cost issues (ongoing) & 1 & 1 & 1 & & \\
\hline & Standardization issues & & 1 & & 1 & \\
\hline & $\begin{array}{l}\text { Quality labelling issues } \\
\text { (R2S etc.) for new } \\
\text { generation of controls }\end{array}$ & 1 & & 1 & & 1 \\
\hline \multirow[t]{2}{*}{$\begin{array}{l}\text { Additional } \\
\text { aspects you } \\
\text { think are } \\
\text { important } \\
\text { (specify and } \\
\text { rank) }\end{array}$} & & & & & & \\
\hline & $\begin{array}{l}\text { Aspects related to } \\
\text { occupants / demand from } \\
\text { occupants }\end{array}$ & & & & & \\
\hline \multirow{12}{*}{$\begin{array}{l}\text { Occupant } \\
\text { control }\end{array}$} & $\begin{array}{l}\text { Simplicity of operation } \\
\text { (switches / interfaces) }\end{array}$ & 3 & & & & \\
\hline & $\begin{array}{l}\text { Design quality of interfaces } \\
\text { (aesthetics / haptic) }\end{array}$ & & 2 & 1 & & \\
\hline & $\begin{array}{l}\text { Capacity to override } \\
\text { control system }\end{array}$ & & 1 & 2 & & \\
\hline & $\begin{array}{l}\text { Manual switching } \\
\text { possibility }\end{array}$ & 1 & & & 1 & \\
\hline & $\begin{array}{l}\text { Manual adjustment of } \\
\text { illuminance level }\end{array}$ & & 2 & 1 & & \\
\hline & $\begin{array}{l}\text { Manual adjustment of } \\
\text { spectrum of light }\end{array}$ & & 3 & & & \\
\hline & Manual control per zone & 2 & 1 & & & \\
\hline & $\begin{array}{l}\text { Automatic adjustment of } \\
\text { illuminance }\end{array}$ & 1 & 2 & & & \\
\hline & $\begin{array}{l}\text { Automatic adjustment of } \\
\text { spectrum of light }\end{array}$ & & 1 & 2 & & \\
\hline & $\begin{array}{l}\text { Automatic lighting control } \\
\text { per zone in the space }\end{array}$ & 3 & & & & \\
\hline & $\begin{array}{l}\text { Capability of occupants to } \\
\text { open shading systems } \\
\text { manually }\end{array}$ & 1 & 1 & & & 1 \\
\hline & $\begin{array}{l}\text { Capability of occupants to } \\
\text { close shading systems } \\
\text { manually }\end{array}$ & 1 & 1 & 1 & & \\
\hline
\end{tabular}




\begin{tabular}{|c|c|c|c|c|c|c|}
\hline & $\begin{array}{l}\text { Ranking of importance: } \\
\begin{array}{c}1=\text { very important to } 3 \text { not } \\
\text { important. }\end{array}\end{array}$ & $\begin{array}{c}1 \\
\text { Important }\end{array}$ & 2 & $\begin{array}{c}3 \\
\text { Not } \\
\text { important }\end{array}$ & $\begin{array}{c}\text { Needs } \\
\text { improvement }\end{array}$ & $\begin{array}{c}\text { Does not need } \\
\text { improvement }\end{array}$ \\
\hline & $\begin{array}{l}\text { Independent control of } \\
\text { ambient and task lighting } \\
\text { (offices, industry) }\end{array}$ & & 3 & & & \\
\hline & $\begin{array}{l}\text { Capacity to override } \\
\text { control system }\end{array}$ & 1 & 1 & & & \\
\hline & $\begin{array}{l}\text { Personal control of lighting } \\
\text { and shading from } \\
\text { workplace }\end{array}$ & 1 & 1 & 1 & & \\
\hline \multirow{5}{*}{$\begin{array}{l}\text { Occupant } \\
\text { comfort }\end{array}$} & $\begin{array}{l}\text { Possibility to limit glare } \\
\text { from windows }\end{array}$ & 2 & & 1 & & \\
\hline & $\begin{array}{l}\text { Possibility to limit } \\
\text { unwanted heat gains }\end{array}$ & 1 & 2 & & & \\
\hline & $\begin{array}{l}\text { Smoothness of transition of } \\
\text { lighting variations to avoid } \\
\text { annoyance }\end{array}$ & 1 & 1 & 1 & & \\
\hline & $\begin{array}{l}\text { Acceptable operation and } \\
\text { coverage area of } \\
\text { occupancy sensors }\end{array}$ & & 2 & & 1 & \\
\hline & $\begin{array}{l}\text { Well-being / psychological } \\
\text { and physiological }\end{array}$ & 2 & & & 1 & \\
\hline \multirow[t]{11}{*}{$\begin{array}{l}\text { Additional } \\
\text { aspects you } \\
\text { think are } \\
\text { important } \\
\text { (specify and } \\
\text { rank) }\end{array}$} & & & & & & \\
\hline & $\begin{array}{l}\text { Aspects related to building } \\
\text { owners / lease holders }\end{array}$ & & & & & \\
\hline & Energy reduction & 3 & & & & \\
\hline & Initial construction costs & 2 & 1 & & & \\
\hline & Running costs & 2 & 1 & & & \\
\hline & "Green" image of building & & 2 & & 1 & \\
\hline & $\begin{array}{l}\text { Clearly perceptible } \\
\text { integration of daylighting } \\
\text { and electric lighting }\end{array}$ & & 2 & 1 & & \\
\hline & $\begin{array}{l}\text { Contribution of the control } \\
\text { systems to potential } \\
\text { "green" certification of the } \\
\text { building }\end{array}$ & 1 & 2 & & & \\
\hline & $\begin{array}{l}\text { User satisfaction / reduced } \\
\text { complaints from user }\end{array}$ & 1 & 1 & & & \\
\hline & $\begin{array}{l}\text { Future proof - flexibility } \\
\text { over long term }\end{array}$ & 1 & 2 & & & \\
\hline & $\begin{array}{l}\text { Signal value of building / } \\
\text { architectural aesthetics }\end{array}$ & & 1 & 2 & & \\
\hline $\begin{array}{l}\text { Additional } \\
\text { aspects you } \\
\text { think are } \\
\text { important }\end{array}$ & & & & & & \\
\hline
\end{tabular}




\begin{tabular}{|c|c|c|c|c|c|c|}
\hline & $\begin{array}{l}\text { Ranking of importance: } \\
\begin{array}{c}1=\text { very important to } 3 \text { not } \\
\text { important. }\end{array}\end{array}$ & $\begin{array}{c}1 \\
\text { Important }\end{array}$ & 2 & $\begin{array}{c}3 \\
\text { Not } \\
\text { important }\end{array}$ & $\begin{array}{c}\text { Needs } \\
\text { improvement }\end{array}$ & $\begin{array}{c}\text { Does not need } \\
\text { improvement }\end{array}$ \\
\hline \multicolumn{7}{|l|}{$\begin{array}{l}\text { (specify and } \\
\text { rank) }\end{array}$} \\
\hline & $\begin{array}{l}\text { New technology } \\
\text { opportunities available }\end{array}$ & & & & & \\
\hline \multirow{13}{*}{$\begin{array}{l}\text { Control } \\
\text { functionality }\end{array}$} & $\begin{array}{l}\text { Open source protocol of } \\
\text { control system }\end{array}$ & 2 & 1 & & & \\
\hline & Wireless capabilities & 1 & 2 & & & \\
\hline & $\begin{array}{l}\text { Compatibility with other } \\
\text { systems (BMS, HVAC, } \\
\text { etc.) }\end{array}$ & 1 & & 1 & & \\
\hline & $\begin{array}{l}\text { Automatic control of } \\
\text { daylight and electric } \\
\text { lighting together }\end{array}$ & 1 & & & 1 & \\
\hline & Daylight responsive control & 1 & & 1 & & \\
\hline & $\begin{array}{l}\text { Integration of occupancy } \\
\text { sensors }\end{array}$ & 2 & 1 & & & \\
\hline & $\begin{array}{l}\text { Integration of other } \\
\text { environmental sensors }\end{array}$ & 2 & 1 & & & \\
\hline & $\begin{array}{l}\text { Internet connection (grid } \\
\text { connected systems) }\end{array}$ & & 3 & & & \\
\hline & DC supply for lighting & & 1 & 1 & & \\
\hline & $\begin{array}{l}\text { Glare responsive control } \\
\text { systems }\end{array}$ & & 1 & & 1 & \\
\hline & $\begin{array}{l}\text { Combined light and heat } \\
\text { control of shading }\end{array}$ & & 2 & & & 1 \\
\hline & $\begin{array}{l}\text { Override features for } \\
\text { occupants }\end{array}$ & 1 & 2 & & & \\
\hline & $\begin{array}{l}\text { Geo-localization } \\
\text { functionalities from } \\
\text { luminaires }\end{array}$ & 1 & 1 & 1 & & \\
\hline $\begin{array}{l}\text { Other } \\
\text { functionalities } \\
\text { associated with } \\
\text { lighting control } \\
\text { (specify) }\end{array}$ & & & & & & \\
\hline
\end{tabular}

\section{Questionnaire conducted in Germany}

In Germany the total respondents are only one and are presenting following areas: Designer Maintenance in the Engineering Industry.

Table 9. Results of survey conducted in Germany.

\begin{tabular}{|l|l|l|l|l|l|l|}
\hline & $\begin{array}{c}\text { Ranking of importance: } \\
\text { 1 = very important to 3 not } \\
\text { important. }\end{array}$ & $\begin{array}{c}1 \\
\text { Important }\end{array}$ & 2 & $\begin{array}{c}\text { Not } \\
\text { important }\end{array}$ & $\begin{array}{c}\text { Needs } \\
\text { improvement }\end{array}$ & $\begin{array}{c}\text { Does not } \\
\text { need } \\
\text { improvement }\end{array}$ \\
\hline & $\begin{array}{l}\text { Demand from building } \\
\text { managers / facility } \\
\text { managers }\end{array}$ & & & & \\
\hline
\end{tabular}




\begin{tabular}{|c|c|c|c|c|c|c|}
\hline & $\begin{array}{l}\text { Ranking of importance: } \\
1=\text { very important to } 3 \text { not } \\
\text { important. }\end{array}$ & $\begin{array}{c}1 \\
\text { Important }\end{array}$ & 2 & $\begin{array}{c}3 \\
\text { Not } \\
\text { important }\end{array}$ & $\begin{array}{l}\text { Needs } \\
\text { improvement }\end{array}$ & $\begin{array}{c}\text { Does not } \\
\text { need } \\
\text { improvement }\end{array}$ \\
\hline \multirow{6}{*}{ Energy aspects } & $\begin{array}{l}\text { Potential for reduction of } \\
\text { lighting electricity } \\
\text { consumption }\end{array}$ & 1 & & & 1 & \\
\hline & $\begin{array}{l}\text { Potential for reduction of } \\
\text { peak lighting electric power }\end{array}$ & & 1 & & & \\
\hline & $\begin{array}{l}\text { Potential of shading system } \\
\text { to reduce heat gains }\end{array}$ & 1 & & & 1 & \\
\hline & $\begin{array}{l}\text { Potential of shading system } \\
\text { to maintain sufficient } \\
\text { daylight penetration }\end{array}$ & 1 & & & 1 & \\
\hline & $\begin{array}{l}\text { Automatic lighting control } \\
\text { related to occupancy } \\
\text { (occupancy sensors) }\end{array}$ & & 1 & & 1 & \\
\hline & $\begin{array}{l}\text { Automatic lighting control } \\
\text { related to daylighting } \\
\text { (daylight-sensors) }\end{array}$ & & 1 & & 1 & \\
\hline \multirow{10}{*}{$\begin{array}{l}\text { Operational } \\
\text { aspects }\end{array}$} & $\begin{array}{l}\text { Easy commissioning / re- } \\
\text { commissioning / calibration }\end{array}$ & 1 & & & 1 & \\
\hline & $\begin{array}{l}\text { Robustness / low failure } \\
\text { rate }\end{array}$ & & 1 & & & \\
\hline & $\begin{array}{l}\text { Simplicity of operation } \\
\text { (general management) }\end{array}$ & 1 & & & 1 & \\
\hline & Warranty / life & & 1 & & & \\
\hline & $\begin{array}{l}\text { Flexibility over long term } \\
\text { (reprogramming of } \\
\text { luminaires according to } \\
\text { new space organization) }\end{array}$ & & 1 & & & \\
\hline & $\begin{array}{l}\text { Future proof concepts (to } \\
\text { ease long term } \\
\text { maintenance and } \\
\text { replacement of equipment) }\end{array}$ & & & & & \\
\hline & Cost issues (initial) & 1 & & & & \\
\hline & Cost issues (ongoing) & 1 & & & 1 & \\
\hline & Standardization issues & & & & & \\
\hline & $\begin{array}{l}\text { Quality labelling issues } \\
\text { (R2S etc.) for new } \\
\text { generation of controls }\end{array}$ & & 1 & & & \\
\hline \multirow[t]{2}{*}{$\begin{array}{l}\text { Additional } \\
\text { aspects you } \\
\text { think are } \\
\text { important } \\
\text { (specify and } \\
\text { rank) }\end{array}$} & & & & & & \\
\hline & $\begin{array}{l}\text { Aspects related to } \\
\text { occupants / demand from } \\
\text { occupants }\end{array}$ & & & & & \\
\hline $\begin{array}{l}\text { Occupant } \\
\text { control }\end{array}$ & $\begin{array}{l}\text { Simplicity of operation } \\
\text { (switches / interfaces) }\end{array}$ & 1 & & & 1 & \\
\hline
\end{tabular}




\begin{tabular}{|c|c|c|c|c|c|c|}
\hline & $\begin{array}{l}\text { Ranking of importance: } \\
1=\text { very important to } 3 \text { not } \\
\text { important. }\end{array}$ & $\begin{array}{c}1 \\
\text { Important }\end{array}$ & 2 & $\begin{array}{c}3 \\
\text { Not } \\
\text { important }\end{array}$ & $\begin{array}{c}\text { Needs } \\
\text { improvement }\end{array}$ & $\begin{array}{c}\begin{array}{c}\text { Does not } \\
\text { need } \\
\text { improvement }\end{array} \\
\end{array}$ \\
\hline & $\begin{array}{l}\text { Design quality of interfaces } \\
\text { (aesthetics / haptic) }\end{array}$ & & 1 & & 1 & \\
\hline & $\begin{array}{l}\text { Capacity to override control } \\
\text { system }\end{array}$ & & 1 & & & \\
\hline & Manual switching possibility & 1 & & & & \\
\hline & $\begin{array}{l}\text { Manual adjustment of } \\
\text { illuminance level }\end{array}$ & 1 & & & & \\
\hline & $\begin{array}{l}\text { Manual adjustment of } \\
\text { spectrum of light }\end{array}$ & & & 1 & & \\
\hline & Manual control per zone & & 1 & & & \\
\hline & $\begin{array}{l}\text { Automatic adjustment of } \\
\text { illuminance }\end{array}$ & & & 1 & & \\
\hline & $\begin{array}{l}\text { Automatic adjustment of } \\
\text { spectrum of light }\end{array}$ & & & 1 & & \\
\hline & $\begin{array}{l}\text { Automatic lighting control } \\
\text { per zone in the space }\end{array}$ & & & 1 & & \\
\hline & $\begin{array}{l}\text { Capability of occupants to } \\
\text { open shading systems } \\
\text { manually }\end{array}$ & 1 & & & & \\
\hline & $\begin{array}{l}\text { Capability of occupants to } \\
\text { close shading systems } \\
\text { manually }\end{array}$ & 1 & & & & \\
\hline & $\begin{array}{l}\text { Independent control of } \\
\text { ambient and task lighting } \\
\text { (offices, industry) }\end{array}$ & 1 & & & & \\
\hline & $\begin{array}{l}\text { Capacity to override control } \\
\text { system }\end{array}$ & & 1 & & & \\
\hline & $\begin{array}{l}\text { Personal control of lighting } \\
\text { and shading from } \\
\text { workplace }\end{array}$ & 1 & & & & \\
\hline \multirow{5}{*}{$\begin{array}{l}\text { Occupant } \\
\text { comfort }\end{array}$} & $\begin{array}{l}\text { Possibility to limit glare } \\
\text { from windows }\end{array}$ & 1 & & & & \\
\hline & $\begin{array}{l}\text { Possibility to limit unwanted } \\
\text { heat gains }\end{array}$ & & 1 & & & \\
\hline & $\begin{array}{l}\text { Smoothness of transition of } \\
\text { lighting variations to avoid } \\
\text { annoyance }\end{array}$ & & & 1 & & \\
\hline & $\begin{array}{l}\text { Acceptable operation and } \\
\text { coverage area of } \\
\text { occupancy sensors }\end{array}$ & & 1 & & & \\
\hline & $\begin{array}{l}\text { Well-being / psychological } \\
\text { and physiological }\end{array}$ & 1 & & & 1 & \\
\hline $\begin{array}{l}\text { Additional } \\
\text { aspects you } \\
\text { think are } \\
\text { important } \\
\text { (specify and } \\
\text { rank) }\end{array}$ & & & & & & \\
\hline
\end{tabular}




\begin{tabular}{|c|c|c|c|c|c|c|}
\hline & $\begin{array}{l}\text { Ranking of importance: } \\
1=\text { very important to } 3 \text { not } \\
\text { important. }\end{array}$ & $\begin{array}{c}1 \\
\text { Important }\end{array}$ & 2 & $\begin{array}{c}3 \\
\text { Not } \\
\text { important }\end{array}$ & $\begin{array}{c}\text { Needs } \\
\text { improvement }\end{array}$ & $\begin{array}{c}\text { Does not } \\
\text { need } \\
\text { improvement }\end{array}$ \\
\hline & $\begin{array}{l}\text { Aspects related to building } \\
\text { owners / lease holders }\end{array}$ & & & & & \\
\hline & Energy reduction & 1 & & & 1 & \\
\hline & Initial construction costs & 1 & & & & \\
\hline & Running costs & 1 & & & & \\
\hline & "Green" image of building & & 1 & & & \\
\hline & $\begin{array}{l}\text { Clearly perceptible } \\
\text { integration of daylighting } \\
\text { and electric lighting }\end{array}$ & & 1 & & & \\
\hline & $\begin{array}{l}\text { Contribution of the control } \\
\text { systems to potential } \\
\text { "green" certification of the } \\
\text { building }\end{array}$ & & & 1 & & \\
\hline & $\begin{array}{l}\text { User satisfaction / reduced } \\
\text { complaints from user }\end{array}$ & 1 & & & 1 & \\
\hline & $\begin{array}{l}\text { Future proof }- \text { flexibility } \\
\text { over long term }\end{array}$ & 1 & & & 1 & \\
\hline & $\begin{array}{l}\text { Signal value of building / } \\
\text { architectural aesthetics }\end{array}$ & & 1 & & & \\
\hline $\begin{array}{l}\text { Additional } \\
\text { aspects you } \\
\text { think are } \\
\text { important } \\
\text { (specify and } \\
\text { rank) }\end{array}$ & & & & & & \\
\hline & $\begin{array}{l}\text { New technology } \\
\text { opportunities available }\end{array}$ & & & & & \\
\hline \multirow{11}{*}{$\begin{array}{l}\text { Control } \\
\text { functionality }\end{array}$} & $\begin{array}{l}\text { Open source protocol of } \\
\text { control system }\end{array}$ & & & 1 & & \\
\hline & Wireless capabilities & & 1 & & & \\
\hline & $\begin{array}{l}\text { Compatibility with other } \\
\text { systems (BMS, HVAC, etc.) }\end{array}$ & 1 & & & 1 & \\
\hline & $\begin{array}{l}\text { Automatic control of } \\
\text { daylight and electric lighting } \\
\text { together }\end{array}$ & 1 & & & 1 & \\
\hline & Daylight responsive control & 1 & & & 1 & \\
\hline & $\begin{array}{l}\text { Integration of occupancy } \\
\text { sensors }\end{array}$ & & 1 & & & \\
\hline & $\begin{array}{l}\text { Integration of other } \\
\text { environmental sensors }\end{array}$ & & 1 & & & \\
\hline & $\begin{array}{l}\text { Internet connection (grid } \\
\text { connected systems) }\end{array}$ & & 1 & & & \\
\hline & DC supply for lighting & & & 1 & & \\
\hline & $\begin{array}{l}\text { Glare responsive control } \\
\text { systems }\end{array}$ & & 1 & & & \\
\hline & $\begin{array}{l}\text { Combined light and heat } \\
\text { control of shading }\end{array}$ & 1 & & & 1 & \\
\hline
\end{tabular}




\begin{tabular}{|c|c|c|c|c|c|c|}
\hline & $\begin{array}{l}\text { Ranking of importance: } \\
1 \text { = very important to } 3 \text { not } \\
\text { important. }\end{array}$ & $\begin{array}{c}1 \\
\text { Important }\end{array}$ & 2 & $\begin{array}{c}3 \\
\text { Not } \\
\text { important }\end{array}$ & $\begin{array}{c}\text { Needs } \\
\text { improvement }\end{array}$ & $\begin{array}{c}\text { Does not } \\
\text { need } \\
\text { improvement }\end{array}$ \\
\hline & $\begin{array}{l}\text { Override features for } \\
\text { occupants }\end{array}$ & & 1 & & & \\
\hline & $\begin{array}{l}\text { Geo-localization } \\
\text { functionalities from } \\
\text { luminaires }\end{array}$ & & & 1 & & \\
\hline $\begin{array}{l}\text { Other } \\
\text { functionalities } \\
\text { associated with } \\
\text { lighting control } \\
\text { (specify) }\end{array}$ & & & & & & \\
\hline
\end{tabular}

